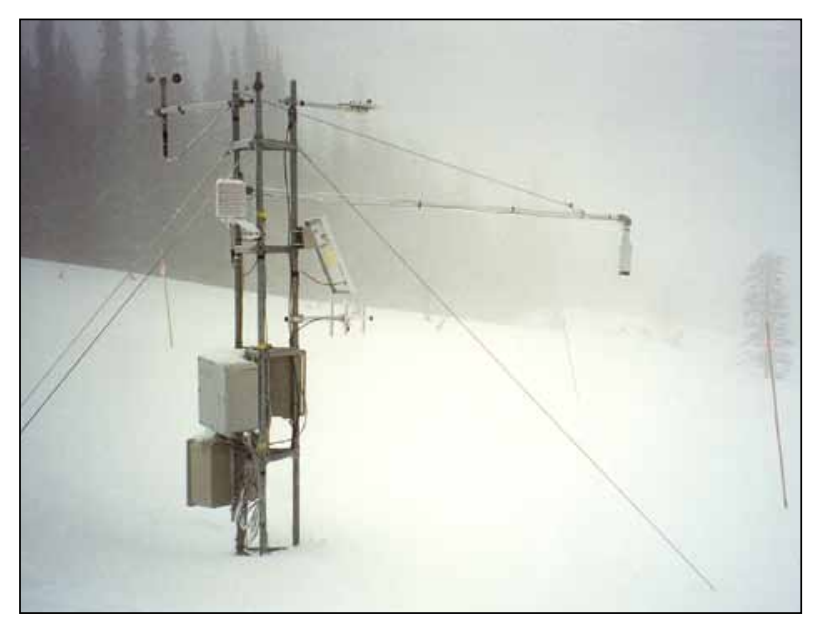

\title{
Weather and Climate
}

R.D. (DAN) MOORE, DAVID L. SPITTLEHOUSE,

PAUL H. WHITFIELD, AND KERSTIN STAHL

\section{INTRODUCTION}

This chapter introduces British Columbia's weather and climate. "Weather" refers to the specific condition of the atmosphere at a particular place and time. It is measured in terms of variables including wind speed and direction, air temperature, humidity, atmospheric pressure, cloudiness, and precipitation. Weather can change from hour to hour, day to day, and season to season. "Climate" is a statistical characterization of the weather, averaged over many years; it is usually represented in terms of means, variability, and extremes of the various weather elements. The following sections focus on (1) the large-scale context of British Columbia's weather and its expression at the scale of synoptic atmospheric circulation; (2) a description of regional climatic variations resulting from the interaction of weather systems with the topography of British Columbia; (3) an overview of large-scale ocean-atmosphere interactions, including El Niño, and their influence on the province's weather and climate; (4) an overview of the climatology and meteorology of extreme hydrogeomorphic events; and (5) a discussion of historic climatic variability and projected future climate change.

\section{ATMOSPHERIC CIRCULATION PATTERNS INFLUENCING BRITISH COLUMBIA}

Alternating sequences of west-to-east flowing lowpressure (cyclonic) and high-pressure (anticyclonic) systems dominate the weather in British Columbia. The low-pressure systems form off the Aleutian Islands in the north Pacific and then migrate easterly to approach the province. These systems are generally associated with fronts, which are the boundaries between warm and cold air masses. Low-pressure systems occur more frequently in winter. During summer, the North Pacific high-pressure system shifts northward into the central-north Pacific and tends to dominate, often producing extended spells of fine weather, particularly in southern British Columbia.
Although the weather situation each day is unique, it is possible to group synoptic-scale conditions into relatively distinctive types based on patterns of sea-level pressure or other atmospheric variables. Stahl et al. (2006b) used a computer-assisted pattern recognition approach to classify daily sea-level pressure patterns into 13 circulation types (Figure 3.1). Airflow can be interpreted from the patterns of the pressure contours (isobars) using the following rules: (1) air tends to flow parallel to the isobars, with anticlockwise flow around lowpressure centres; and (2) wind speed is related to the isobar spacing, with tighter spacing indicating stronger winds. The monthly variation in synoptic 
Type 1
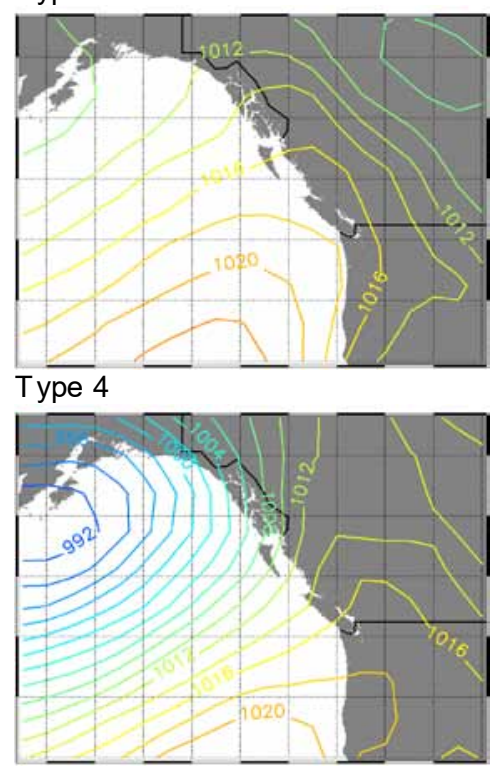

Type 7

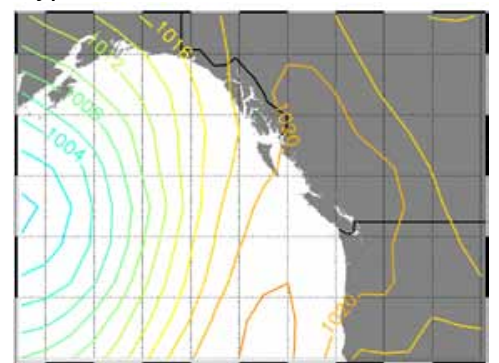

Type 10

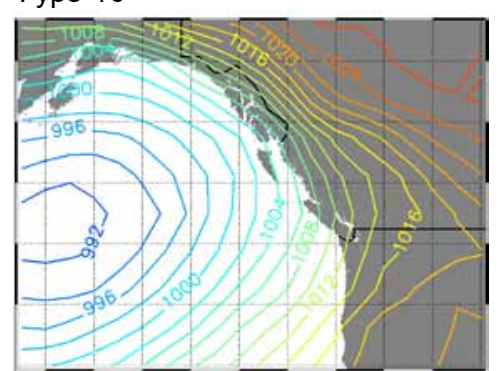

Type 13

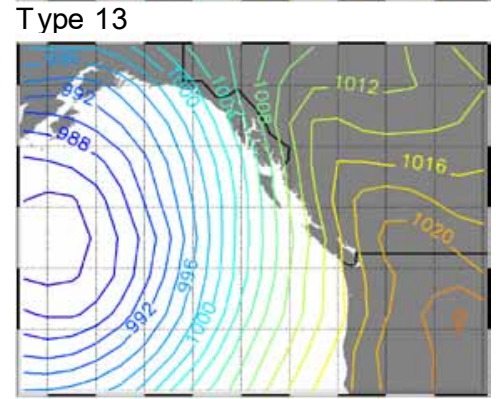

FIGURE 3.1 Composites of sea-level pressure patterns associated with the 13 synoptic types. (Adapted from Stahl et al. 2006b)
Type 2

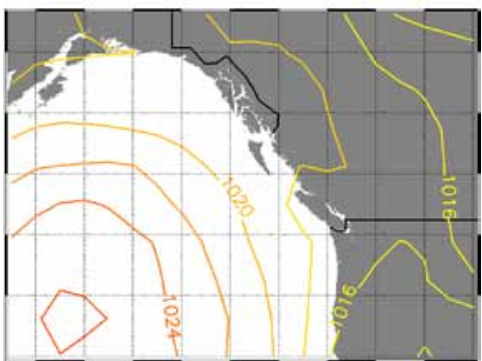

Type 5

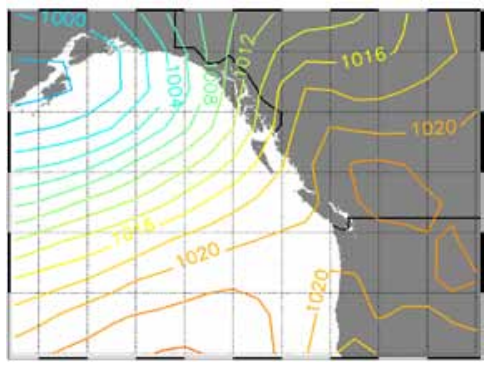

Type 8

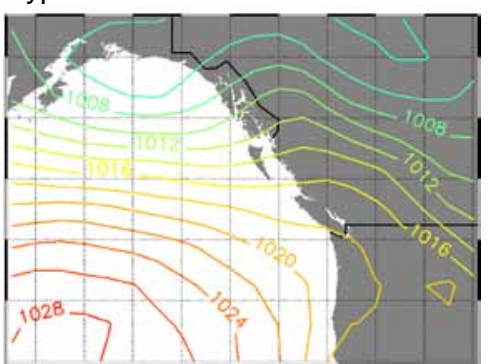

Type 11

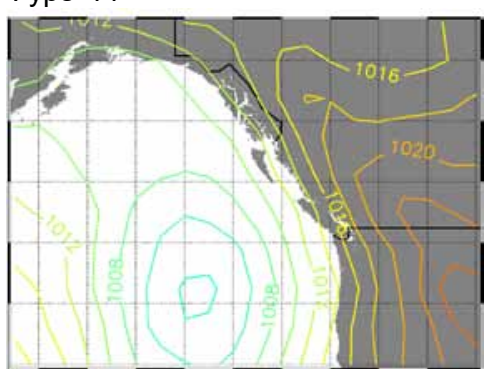

Type 12

Type 9
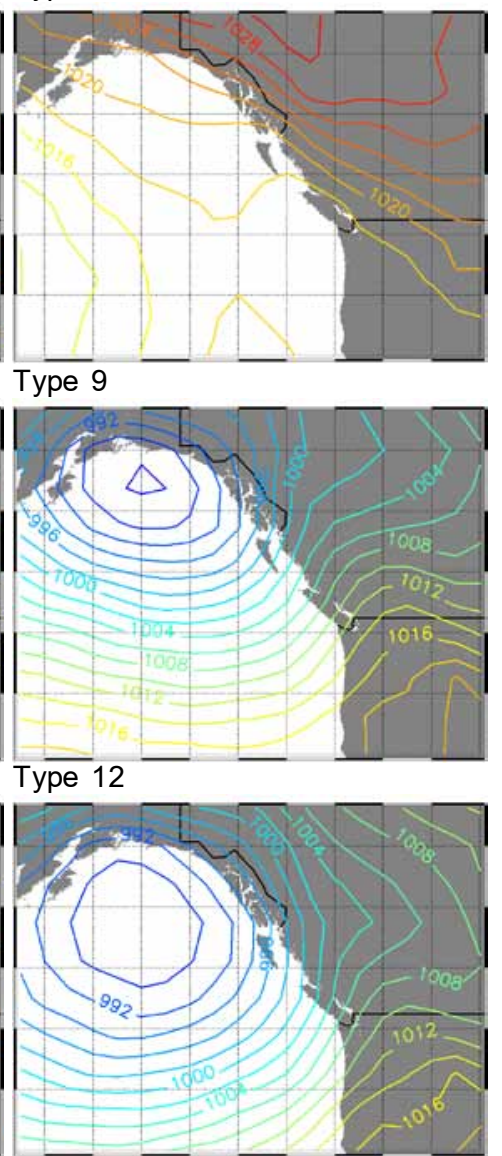

Type 3

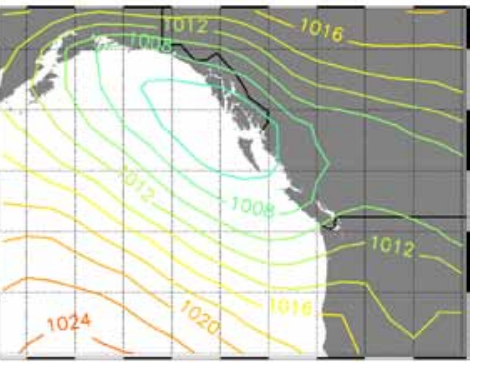

Type 6 
type frequency is shown in Figure 3.2. Types 1 and 2 are the most frequent circulation types. They occur year-round, but dominate British Columbia's climate during the summer months. Together with Type 8 , these types represent systems dominated by the presence of the Pacific High just off the coast. The mainly meridional (south-north) flow over British Columbia (Types 1 and 2) is typical for dry and fine summer weather, whereas the southern position of the High in Type 8 causes more zonal (west-east) flow with unstable weather.

During autumn, winter, and spring, British Columbia's synoptic climatology is more variable, and most of the circulation types occur with a similar frequency between November and February. Circulation Types 3-7 are distributed most evenly throughout the year, but all have a minimum in summer. These types represent a mix of patterns and influences on the provincial climate. The Aleutian Low is visible in all of these patterns, except for Type 6. All involve some influence of continental highpressure systems over British Columbia. Perhaps with the exception of Type 6, which has a high persistence, these patterns are not very stable and tend to be transitional within the typical mid-latitude circulation characterized by a series of frontal systems moving from west to east. Types 9 through 13 occur mainly in winter, and are all characterized by an Aleutian Low of varying location and depth. Southwesterly flow over British Columbia is common during these situations.

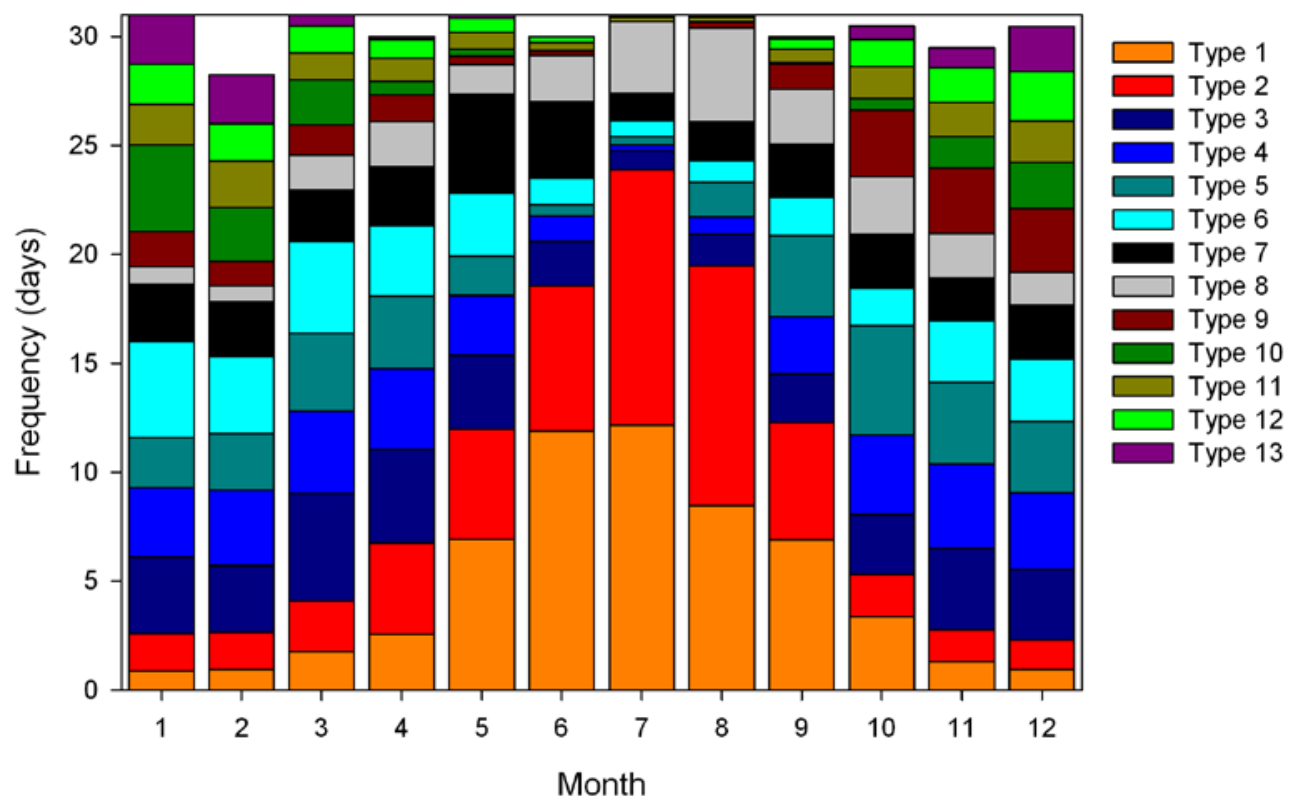

FIGURE 3.2 Mean frequencies of synoptic types by month. Types 1, 2, and 8 dominate in summer, Types 3-7 occur year-round, and Types 9-13 dominate in winter. (Adapted from Stahl et al. 2006b)

\section{REGIONAL CLIMATES OF BRITISH COLUMBIA}

The interaction of large-scale weather systems with the topography of British Columbia's land surface produces distinctive climatic patterns that vary with elevation, distance from the coast, exposure to the prevailing winds, and season. This section describes the spatial and temporal variability of climate within British Columbia.

\section{Climatic Zones}

British Columbia can be divided into five physiographic regions that have distinct macroclimatic regimes (Figure 3.3) (Valentine et al. 1978; Phillips 1980; Chilton 1981). The numerous parallel mountain ranges and extensive plateaus, plains, and basins 


\section{PHYSIOGRAPHIC REGIONS}

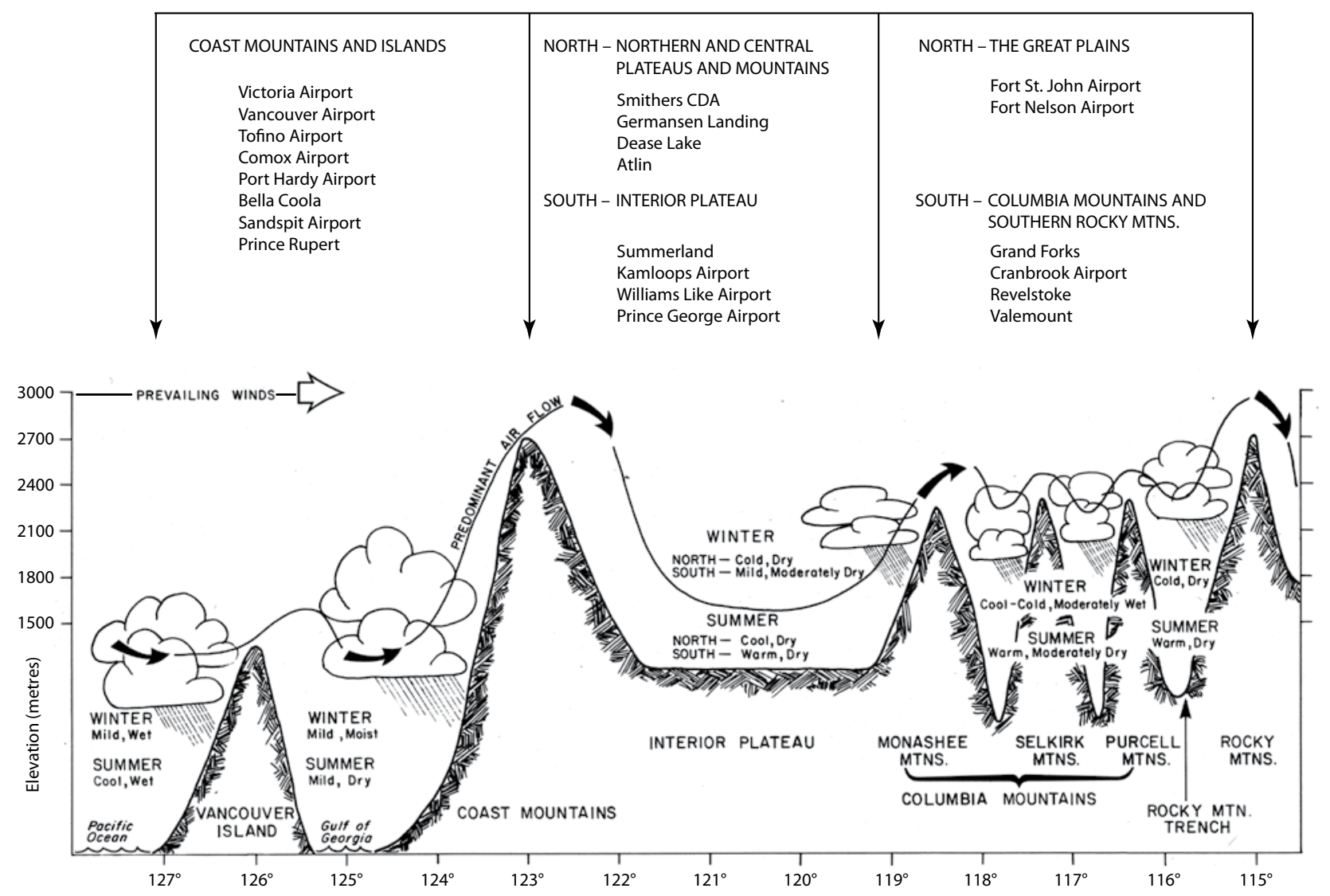

FIGURE 3.3 Latitudinal cross-section through southern British Columbia illustrating physiographic diversity and resulting climatic regimes. Listed in the upper part of the figure are the five major physiographic regions and associated weather stations within these climates. (Adapted from Chilton 1981)

produce a range of climatic regimes that is reflected in 14 vegetation zones named from the dominant tree species of the zone (Figure 3.4, Tables 3.1 and 3.2). The zones range from cool, moist coastal forests to warm, dry interior forests, and from Garry oak parkland to black spruce muskeg. Mediterraneantype, semi-arid, subarctic, and alpine climates also occur, supporting extensive areas of open forest, grassland, scrub, and tundra.

The mountain ranges, which lie roughly perpendicular to the dominant large-scale airflow, largely determine the overall distribution of precipitation and the balance between Pacific and continental air masses in the various regions of British Columbia. The wettest climates of British Columbia (and Canada) occur on the outer coast, especially near the mountains on the windward slopes of Vancouver Island, the Queen Charlotte Islands, and the mainland Coast Mountains (Figures 3.5 and 3.6). Here, moist air carried by prevailing westerly winds drops large amounts of rain or snow as it is forced up the mountain slopes. The air descends over the eastern slopes and is warmed by compression, causing the clouds to thin out. The driest climates of British Columbia, located in the valley bottoms of the south-central Interior, are in the rain shadow of the Coast Mountains (Figure 3.5). Travelling farther eastward, the air releases additional moisture as it ascends successive ranges, including the Columbia and Rocky Mountains in the south, and the Skeena, Omineca, Cassiar, and Rocky Mountains in the north. The mountains restrict the westward flow of cold, continental arctic air masses from east of the Rocky Mountains, thus moderating the winter climate in the southern Interior. In spring, the Interior has little precipitation, but early summer is often relatively wet. By midsummer, however, interior storms and precipitation decline again. In middle and late summer, the Pacific 


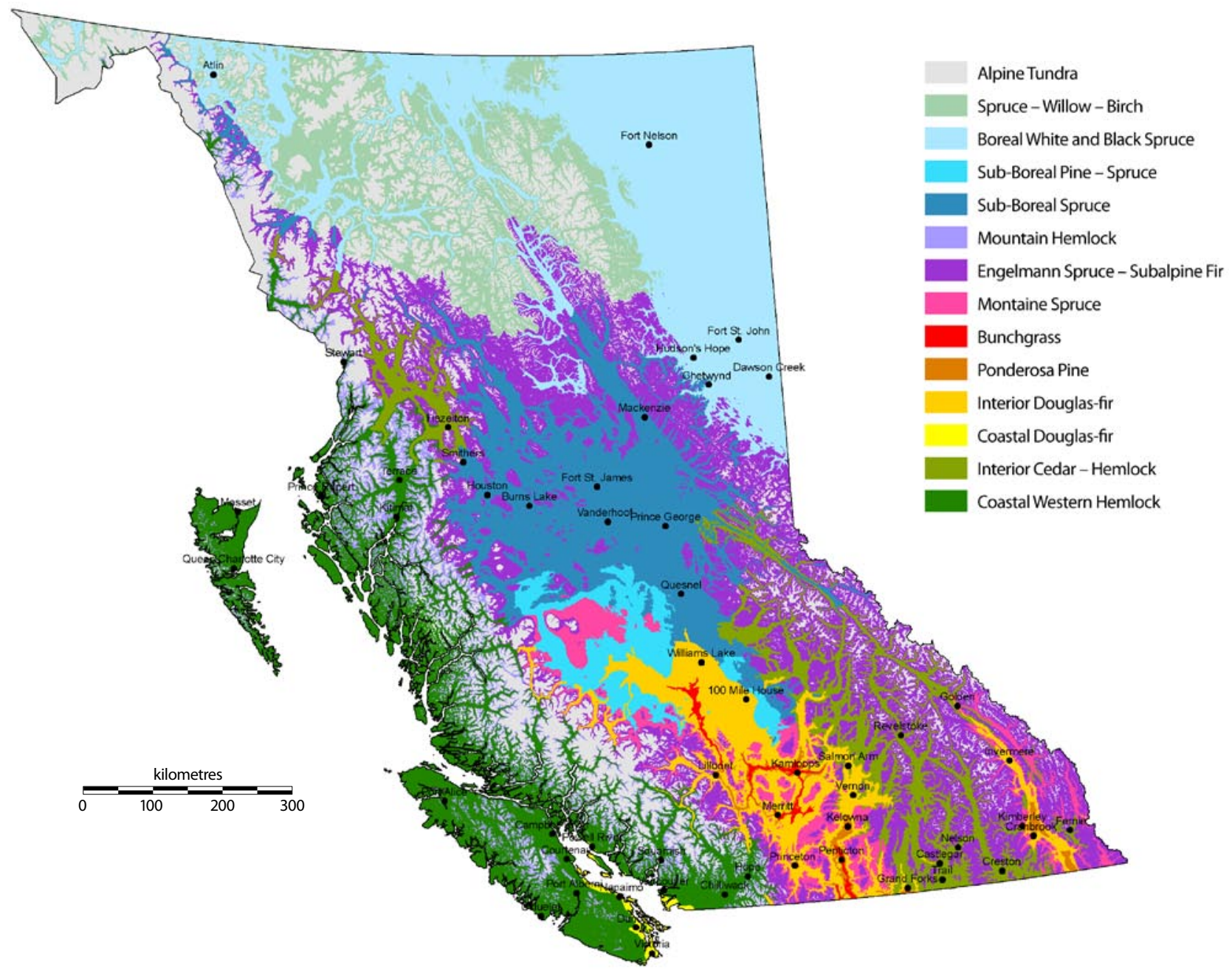

FIGURE 3.4 Biogeoclimatic zones of British Columbia (B.C. Ministry of Forests and Range 2008).
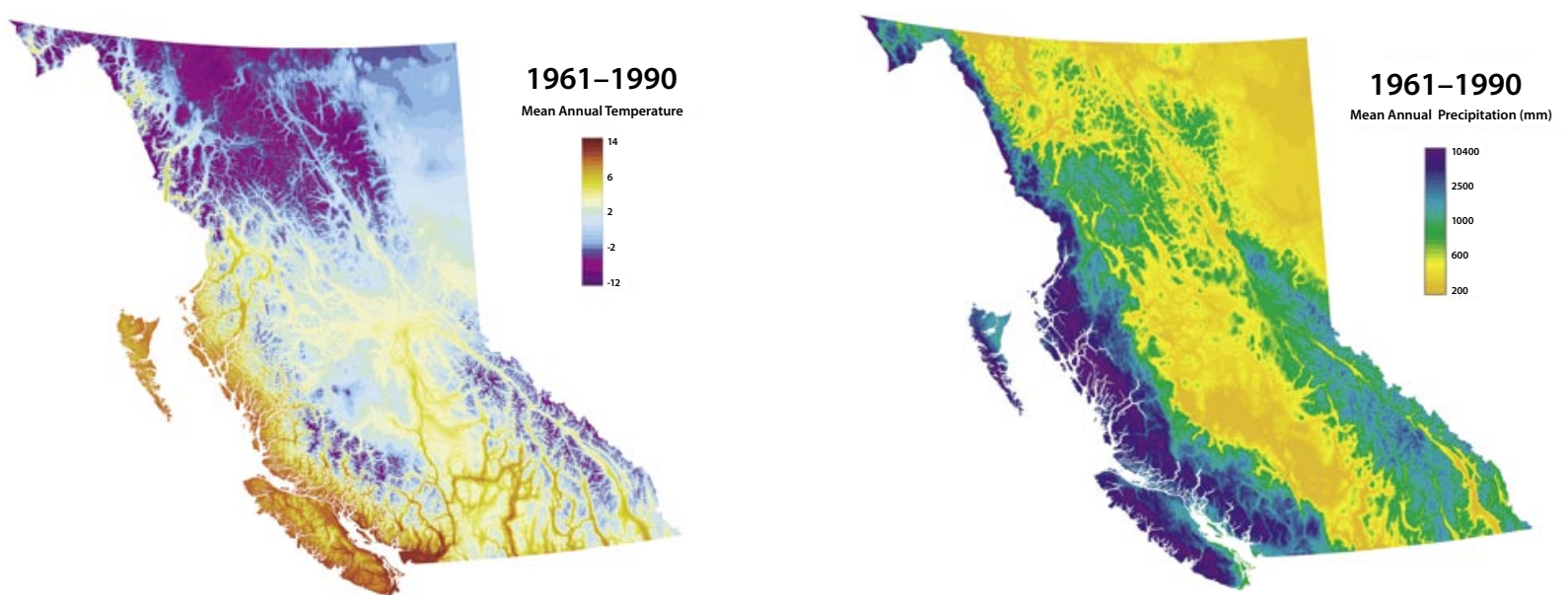

FIGURE 3.5 Mean annual temperature and mean annual precipitation for the 1961-1990 period. Data interpolated using ClimateBC (Spittlehouse 2006, 2008; Wang et al. 2006). 
TABLE 3.1 1961-1990 climate normals for zones of the biogeoclimatic ecosystem classification system. Climate variable and zone abbreviations are explained below the table. Data are based on information at ftp://ftp.for.gov.bc.ca/HRE/external/ !publish/Climate/.

\begin{tabular}{|c|c|c|c|c|c|c|c|c|c|c|c|}
\hline Zone $^{a}$ & $\begin{array}{l}\text { MAP }^{\mathbf{b}} \\
(\mathbf{m m})\end{array}$ & $\begin{array}{l}\text { MSP } \\
(\mathbf{m m})\end{array}$ & $\begin{array}{l}\text { PAS } \\
(\mathbf{m m})\end{array}$ & $\begin{array}{l}\text { MAT } \\
\left({ }^{\circ} \mathrm{C}\right)\end{array}$ & $\begin{array}{l}\text { MCMT } \\
\left({ }^{\circ} \mathrm{C}\right)\end{array}$ & $\begin{array}{l}\text { MWMT } \\
\left({ }^{\circ} \mathrm{C}\right)\end{array}$ & $\begin{array}{l}\text { xTmin } \\
\left({ }^{\circ} \mathrm{C}\right)\end{array}$ & $\begin{array}{l}\text { FFP } \\
\text { (days) }\end{array}$ & $\mathbf{D D}<\mathbf{0}$ & DD $>5$ & SH:M \\
\hline BAFA & 1090 & 447 & 598 & -2.6 & -13.4 & 9.1 & -44.6 & 15 & 2071 & 340 & 22 \\
\hline BG & 342 & 161 & 100 & 6.1 & -6.3 & 17.5 & -35.8 & 118 & 575 & 1717 & 114 \\
\hline BWBS & 514 & 308 & 178 & -0.3 & -16.0 & 14.3 & -46.5 & 77 & 2090 & 1023 & 48 \\
\hline CDF & 1091 & 201 & 61 & 9.6 & 3.0 & 16.9 & -15.4 & 204 & 31 & 1965 & 88 \\
\hline CMA & 3198 & 816 & 1795 & -0.3 & -9.7 & 9.6 & -40.0 & 43 & 1364 & 440 & 14 \\
\hline CWH & 2893 & 651 & 427 & 6.7 & -0.4 & 14.5 & -22.1 & 151 & 191 & 1339 & 27 \\
\hline ESSF & 1096 & 404 & 566 & 0.3 & -10.6 & 11.5 & -41.8 & 51 & 1413 & 650 & 30 \\
\hline ICH & 920 & 342 & 379 & 3.3 & -8.4 & 14.7 & -38.9 & 88 & 922 & 1152 & 45 \\
\hline IDF & 493 & 210 & 178 & 4.0 & -7.7 & 15.1 & -38.6 & 84 & 813 & 1238 & 74 \\
\hline IMA & 1539 & 473 & 959 & -2.0 & -11.3 & 8.4 & -43.1 & 20 & 1791 & 301 & 19 \\
\hline MH & 3119 & 730 & 1198 & 2.8 & -5.7 & 12.0 & -33.2 & 76 & 690 & 781 & 19 \\
\hline MS & 648 & 261 & 292 & 1.9 & -9.3 & 12.8 & -40.8 & 62 & 1101 & 848 & 51 \\
\hline PP & 382 & 165 & 112 & 6.3 & -5.9 & 17.9 & -35.2 & 120 & 517 & 1762 & 112 \\
\hline SBPS & 473 & 228 & 191 & 1.7 & -10.3 & 12.6 & -43.2 & 35 & 1176 & 843 & 57 \\
\hline SBS & 657 & 280 & 274 & 2.2 & -10.3 & 13.6 & -41.9 & 75 & 1169 & 988 & 19 \\
\hline SWB & 691 & 352 & 322 & -1.8 & -13.9 & 10.9 & -44.6 & 37 & 2038 & 525 & 12 \\
\hline
\end{tabular}

a $\quad$ BAFA = Boreal Alti Fescue Alpine; $B G=$ Bunchgrass; $B W B S=$ Boreal Black and White Spruce; CDF = Coastal Douglas-fir; CMA $=$ Coastal Mountain-heather Alpine; $\mathrm{CWH}=$ Coastal Western Hemlock; ESSF $=$ Engelmann Spruce-Subalpine Fir; ICH $=$ Interior Cedar-Hemlock; IDF = Interior Douglas-fir; IMA = Interior Mountain-heather Alpine; $\mathrm{MH}=$ Mountain Hemlock; MS = Montane Spruce; PP = Ponderosa Pine; SBPS = Sub-boreal Pine-Spruce; SBS = Sub-boreal Spruce; SWB = Spruce-Willow-Birch.

b $\quad$ MAP = mean annual precipitation; MSP = mean summer precipitation (May to September); PAS = precipitation as snow (water equivalent); $\mathrm{MAT}=$ mean annual temperature; $\mathrm{MCMT}=$ mean coldest month temperature (January); $\mathrm{MWMT}=$ mean warmest month temperature (July); $x$ Tmin $=$ extreme minimum temperature; $F F P=$ frost-free period; $\mathrm{DD}<\mathrm{O}=$ degree-days less than $\mathrm{O}^{\circ} \mathrm{C} ; \mathrm{DD}>5=$ degree-days greater than $5^{\circ} \mathrm{C}$; $\mathrm{SH}: \mathrm{M}=$ summer heat:moisture index.

TABLE 3.2 One standard deviation on mean values of 1961-1990 climate normals for zones of the biogeoclimatic ecosytem classification system presented in Table 3.1. Climate variable and zone abbreviations are listed in Table 3.1.

\begin{tabular}{|c|c|c|c|c|c|c|c|c|c|c|c|}
\hline Zone & $\begin{array}{l}\text { MAP } \\
(\mathbf{m m})\end{array}$ & $\begin{array}{l}\text { MSP } \\
(\mathbf{m m})\end{array}$ & $\begin{array}{l}\text { PAS } \\
(\mathbf{m m})\end{array}$ & $\begin{array}{l}\text { MAT } \\
\left({ }^{\circ} \mathrm{C}\right)\end{array}$ & $\begin{array}{l}\text { MCMT } \\
\left({ }^{\circ} \mathrm{C}\right)\end{array}$ & $\begin{array}{l}\text { MWMT } \\
\left({ }^{\circ} \mathrm{C}\right)\end{array}$ & $\begin{array}{l}\text { xTmin } \\
\left({ }^{\circ} \mathrm{C}\right)\end{array}$ & $\begin{array}{l}\text { FFP } \\
\text { (days) }\end{array}$ & $\mathbf{D D}<\mathbf{0}$ & $\mathrm{DD}>5$ & SH:M \\
\hline BAFA & 524 & 150 & 345 & 1.2 & 1.6 & 1.2 & 1.5 & 19 & 330 & 114 & 7 \\
\hline BG & 30 & 19 & 12 & 0.5 & 0.5 & 0.6 & 1.1 & 9 & 66 & 134 & 16 \\
\hline BWBS & 61 & 37 & 24 & 0.7 & 2.1 & 0.7 & 1.4 & 8 & 259 & 107 & 7 \\
\hline CDF & 166 & 47 & 13 & 0.3 & 0.5 & 0.4 & 1.3 & 19 & 14 & 87 & 18 \\
\hline CMA & 1252 & 397 & 737 & 2.2 & 3.5 & 1.9 & 5.0 & 32 & 554 & 218 & 7 \\
\hline CWH & 785 & 186 & 205 & 0.9 & 1.4 & 0.9 & 3.2 & 23 & 88 & 181 & 8 \\
\hline ESSF & 251 & 76 & 156 & 0.8 & 0.9 & 0.8 & 1.2 & 15 & 176 & 116 & 6 \\
\hline ICH & 197 & 59 & 111 & 1.0 & 1.0 & 1.0 & 1.7 & 14 & 162 & 175 & 9 \\
\hline IDF & 82 & 27 & 39 & 0.7 & 0.7 & 0.9 & 1.3 & 13 & 101 & 160 & 11 \\
\hline IMA & 351 & 113 & 251 & 1.2 & 1.2 & 1.4 & 1.6 & 20 & 278 & 133 & 6 \\
\hline MH & 888 & 234 & 446 & 1.3 & 2.0 & 1.3 & 3.8 & 28 & 254 & 192 & 7 \\
\hline MS & 128 & 46 & 74 & 0.6 & 0.7 & 0.7 & 1.0 & 11 & 103 & 110 & 10 \\
\hline PP & 43 & 17 & 19 & 0.7 & 0.6 & 0.8 & 1.3 & 10 & 78 & 161 & 15 \\
\hline SBPS & 55 & 32 & 31 & 0.6 & 0.7 & 0.7 & 1.0 & 18 & 90 & 104 & 11 \\
\hline SBS & 107 & 38 & 58 & 0.6 & 0.8 & 0.6 & 1.0 & 11 & 108 & 104 & 3 \\
\hline SWB & 134 & 77 & 89 & 0.7 & 1.5 & 0.8 & 1.2 & 18 & 191 & 97 & 3 \\
\hline
\end{tabular}



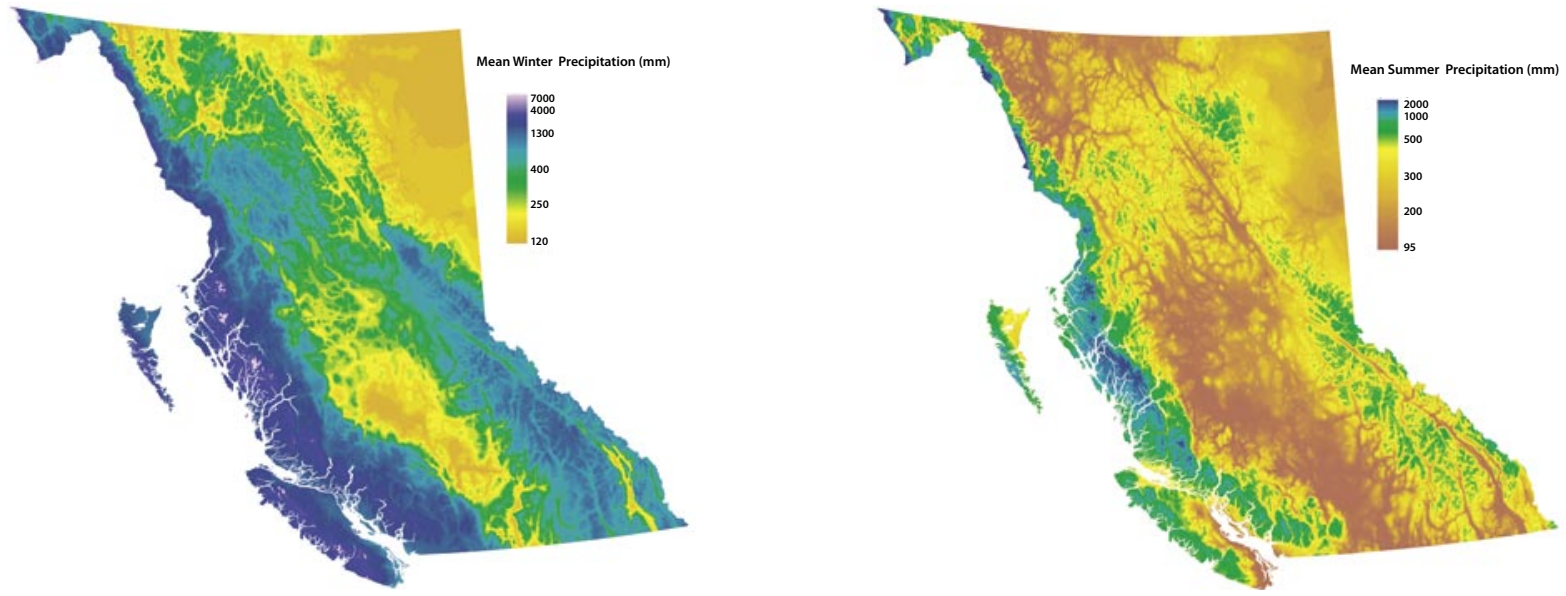

FIGURE 3.6 Mean October to April and mean May to September precipitation for the 1961-1990 period. Data interpolated using ClimateBC (Spittlehouse 2006, 2008; Wang et al. 2006).

High often dominates western North America, giving warm, clear weather to much of British Columbia, except where it generates convective cells and precipitation in the afternoon and early evening.

Air temperatures vary with distance from the coast and with latitude (Figures 3.5 and 3.7). Higher mean annual temperatures are found on the coast and inland in valley bottoms. Mean annual temperatures generally decrease to the north and (or) with increasing elevation. Summer temperatures are often higher in the Interior than on the Coast, with the reverse pattern holding for winter temperatures. The annual temperature range is greatest in the northern Interior of the province. Temperature variations from day to day tend to be greater in winter, and are largely controlled by the origin of the dominant air mass (e.g., arctic continental vs. maritime). Diurnal temperature ranges are generally greater in summer than winter, reflecting the seasonal variation in solar radiation.
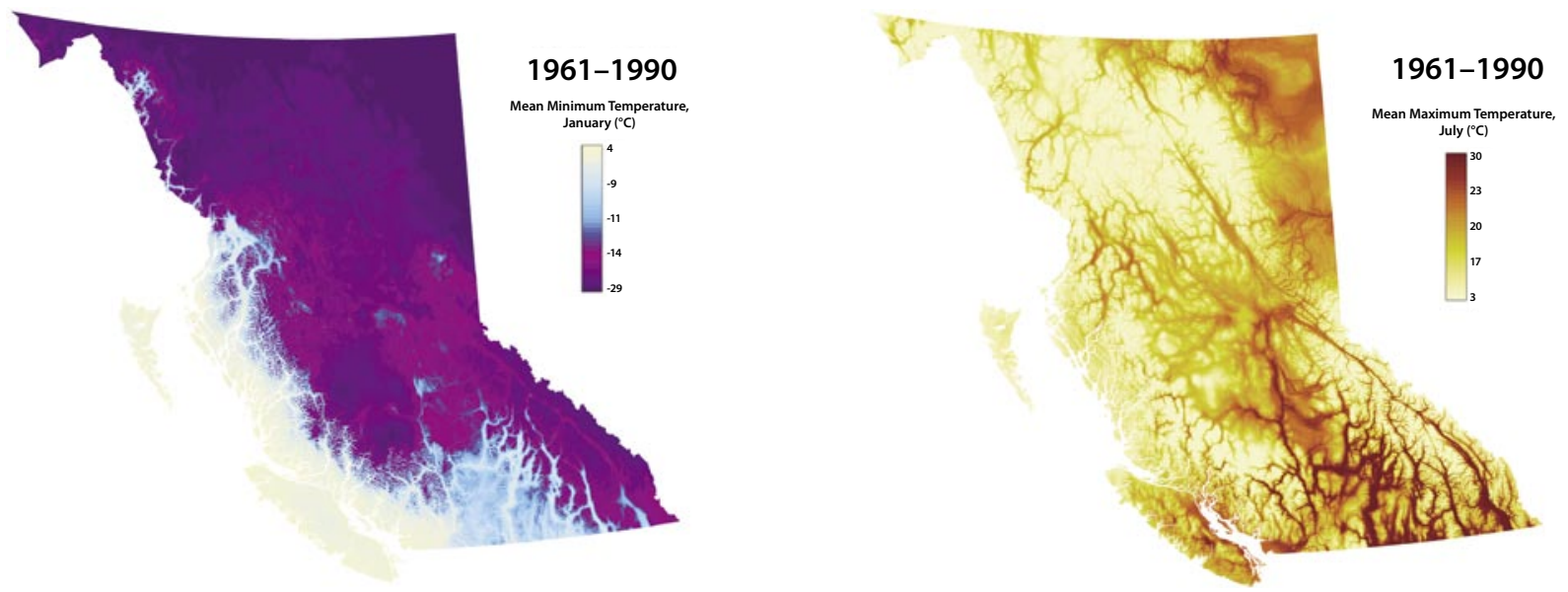

FIGURE 3.7 Mean January minimum and mean July maximum air temperature for the 1961-1990 period. Data interpolated using ClimateBC (Spittlehouse 2006, 2008; Wang et al. 2006). 
Air temperature, precipitation, and other climatic elements vary seasonally because of the combined effects of varying solar radiation and weather-type frequency. For example, coastal stations are dominated by a winter-wet, summer-dry pattern because of the increased frequency of high-pressure systems and associated reduction in frontal and cyclonic weather (e.g., Figure 3.8; Nanaimo and Prince Rupert). In the lee of the Coast Mountains and throughout much of the Interior, precipitation exhibits weaker or little seasonality (e.g., Figure 3.8; Penticton, Upper Penticton Creek, Dease Lake, and Prince George).

Of particular importance to hydrogeomorphic processes is the climatic moisture regime, which reflects the balance between the precipitation falling on an area and the evaporative demand for water. The evaporative demand is a function of solar radiation, air temperature, humidity, and wind speed, and is represented by a monthly reference evaporation $\left(\mathrm{E}_{\mathrm{ref}}\right)$. The climatic moisture deficit (CMD) equals the monthly $\mathrm{E}_{\text {ref }}$ minus the monthly precipitation; $\mathrm{CMD}$ is zero if precipitation exceeds $\mathrm{E}_{\mathrm{ref}}$, in which case there is a moisture surplus. During periods of high CMD, streamflow will typically drop to low levels, sustained by the discharge from surface storage (lakes, ponds, and wetlands) and groundwater. The exception to this situation occurs in catchments with more than about $5 \%$ glacier cover, where increased glacier melt during hot, dry weather can increase streamflow (Stahl and Moore 2006).

To illustrate variations in British Columbia's climatic moisture regimes, moisture deficits and surpluses were determined for eleven Meteorological Service of Canada weather stations with data from 1971 to 2000, one high-elevation research station (Winkler et al. 2004), two long-term weather station records for coastal British Columbia (Spittlehouse 2003, 2004), and three locations with interpolated values (1961-1990 normals). Calculations for other locations show that the shorter-period data yield values that are within 5\% of those for the longer period. The calculated $\mathrm{CMD}$ and $\mathrm{E}_{\text {ref }}$ were then averaged by month over the calculation period. Note that the use of monthly averages, although common, obscures some details of the seasonal variations in climatic conditions. Site factors, such as the vegetation cover, topographic shading, soil characteristics, and location on a slope, may exacerbate or ameliorate climatic moisture conditions. The influence of site factors is discussed in Chapter 17 ("Watershed Measurement Methods and Data Limitations").

The reference evaporation rate $\left(\mathrm{E}_{\mathrm{ref}}\right)$ was calculated with the Penman-Monteith equation for a $0.12 \mathrm{~m}$ tall grass surface (Allen et al. 1998) on a monthly time step from 1970 to 2005 (see footnote in Table 3.3 for details). The Thornthwaite equation (Thornthwaite 1948; Mather and Ambroziak 1986) was used to determine $\mathrm{E}_{\text {ref }}$ for stations where only temperature and precipitation data were available. A comparison of the Thornthwaite with the PenmanMonteith equation showed that it tended to overestimate the monthly evaporation and CMD, consistent with the analysis of Mather and Ambroziak (1986). In both methods, the monthly $\mathrm{E}_{\mathrm{ref}}$ is zero if the monthly average temperature is less than or equal to zero. This approach, while appropriate for estimating soil moisture deficits, ignores sublimation and evaporation of intercepted snow on trees or from open areas. These processes are difficult to estimate, however. Values of $\mathrm{E}_{\text {ref }}$ are zero for large parts of the winter, but can be $0.5 \mathrm{~mm} / \mathrm{d}$ for forests under favourable conditions. Events such as chinook (foehn) winds can produce high rates of loss from forests and open areas. In the southern Interior of British Columbia, winter interception loss of snow by forests is $20-60 \mathrm{~mm}$ depending on precipitation regime. Sublimation and evaporative losses from openings will be much lower than canopy interception losses in the forest. These processes are discussed in more detail in Chapter 7 ("The Effects of Forest Disturbance on Hydrologic Processes and Watershed Response").

The climatic moisture regimes are summarized in Figure 3.8 and Tables 3.3 and 3.4. As expected, warmer and drier environments have a higher evaporative demand and greater CMD. Cool, wet coastal locations, such as Prince Rupert, show no deficit in most months and only in some years. The cloudy environment reduces solar radiation and the ocean moderates summer temperature such that, although evaporation can take place over most of the year, there is a lower $\mathrm{E}_{\text {ref }}$ than in the cold areas, such as Dease Lake and Fort St. John. Dry interior sites, such as Penticton, Kamloops, and Cranbrook, have high $\mathrm{E}_{\text {ref }}$ that, combined with a low summer precipitation, results in high CMD. Penticton and Upper Penticton Creeks (Figure 3.8) show the influence of elevation. The lower air temperature and slightly reduced 

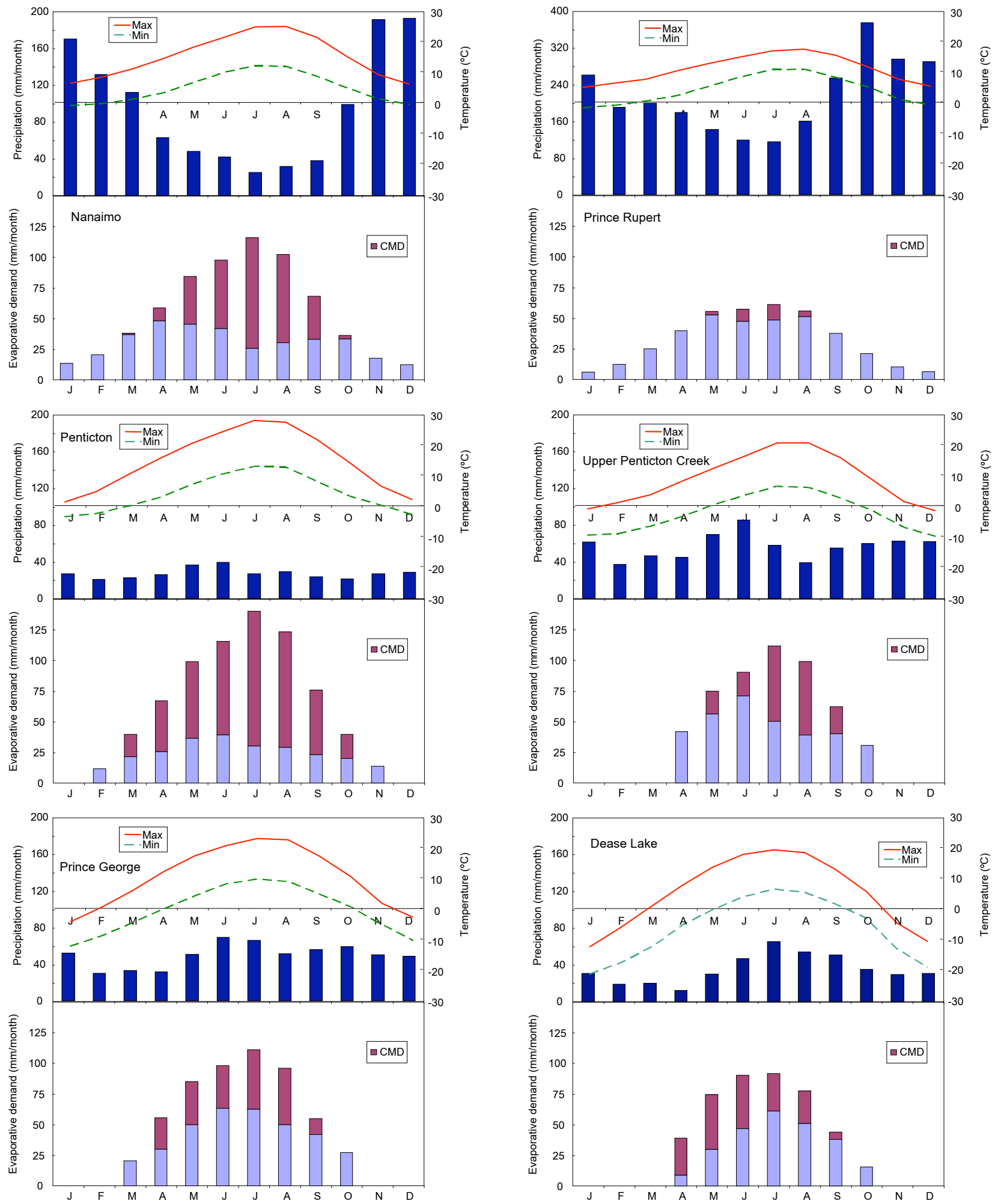

FIgURE 3.8 Climate diagrams for Nanaimo, Prince Rupert, Penticton, Upper Penticton Creek, Prince George, and Dease Lake. Data are averages for 1970-2005 except Upper Penticton Creek, which is for 1992-2005. The upper panel of each station shows the mean monthly maximum (red solid line) and minimum (green dashed line) air temperature and the monthly precipitation (dark blue bars). The precipitation scale for Prince Rupert is double that of the other locations. The lower panel shows the climatic moisture deficit (purple bar) and the reference evaporation (light blue plus purple bar). See Tables 3.3 and 3.4 for more details on each location. 
solar radiation result in a lower $\mathrm{E}_{\text {ref }}$ that, combined with high precipitation, reduces the CMD at Upper Penticton Creek. The higher-elevation site also has a shorter season in which evaporation can occur.

Variation in $\mathrm{E}_{\text {ref }}$ between years is usually about $5 \%$; however, variations in precipitation are much greater and result in the monthly CMD varying by up to $100 \%$ (Table 3.3). Some of the early and late months in the year have a small CMD even though the average precipitation is greater than the average $\mathrm{E}_{\mathrm{ref}}$. This is because the variability in annual precipitation results in a deficit in some years and not in

TABLE 3.3 Reference evaporation $\left(E_{\text {ref }}\right)$ and climatic moisture deficit (CMD) for selected locations and the biogeoclimatic ecosystem classification (BEC) zone in which they occur. SD is standard deviation of the average. Data are calculated using monthly data from 1971 to 2000, or monthly data from 1992 to 2004. For an explanation of BEC zone abbreviations, see Table 3.1.

\begin{tabular}{|c|c|c|c|c|c|c|c|c|}
\hline Location $^{a}$ & $\begin{array}{l}\text { BEC } \\
\text { zone }\end{array}$ & Latitude & Longitude & $\begin{array}{l}\text { Elevation } \\
(\mathrm{m})\end{array}$ & $\begin{array}{l}\mathrm{E}_{\mathrm{ref}}^{\mathrm{b}} \\
(\mathbf{m m})\end{array}$ & $\begin{array}{l}\text { SD } \\
(\mathrm{mm})\end{array}$ & $\begin{array}{l}\text { CMD } \\
(\mathrm{mm})\end{array}$ & $\begin{array}{l}\text { SD } \\
(\mathrm{mm})\end{array}$ \\
\hline Cranbrook & IDF & $49^{\circ} 37^{\prime}$ & $115^{\circ} 47^{\prime}$ & 939 & 680 & 20 & 422 & 68 \\
\hline Dease Lake & BWBS & $58^{\circ} 25^{\prime}$ & $130^{\circ} 00^{\prime}$ & 816 & 433 & 25 & 182 & 54 \\
\hline Fort St John A & BWBS & $56^{\circ} 14^{\prime}$ & $120^{\circ} 44^{\prime}$ & 695 & 487 & 36 & 199 & 70 \\
\hline Kamloops A & BG & $50^{\circ} 42^{\prime}$ & $120^{\circ} 27^{\prime}$ & 345 & 735 & 30 & 531 & 68 \\
\hline Nanaimo A & $\mathrm{CDF}$ & $49^{\circ} 03^{\prime}$ & $123^{\circ} 52^{\prime}$ & 30 & 664 & 28 & 307 & 62 \\
\hline Penticton A & BG & $49^{\circ} 28^{\prime}$ & $119^{\circ} 36^{\prime}$ & 344 & 732 & 23 & 479 & 66 \\
\hline Upper Penticton Creek & ESSF & $49^{\circ} 39^{\prime}$ & $119^{\circ} 24^{\prime}$ & 1620 & 514 & 29 & 191 & 74 \\
\hline Prince George A & SBS & $53^{\circ} 53^{\prime}$ & $122^{\circ} 41^{\prime}$ & 676 & 551 & 27 & 209 & 72 \\
\hline Prince Rupert A & CWH & $54^{\circ} 18^{\prime}$ & $130^{\circ} 26^{\prime}$ & 34 & 388 & 18 & 9 & 16 \\
\hline Smithers A & SBS & $54^{\circ} 49^{\prime}$ & $127^{\circ} 11^{\prime}$ & 523 & 503 & 31 & 233 & 65 \\
\hline Tofino & CWH & $49^{\circ} 05^{\prime}$ & $125^{\circ} 46^{\prime}$ & 24 & 522 & 19 & 62 & 43 \\
\hline Victoria A & $\mathrm{CDF}$ & $49^{\circ} 39^{\prime}$ & $123^{\circ} 26^{\prime}$ & 20 & 633 & 24 & 336 & 61 \\
\hline
\end{tabular}

a Locations with an "A" following the name indicate measurements made at airports

b $\mathrm{E}_{\mathrm{ref}}$ was calculated using the Penman-Monteith equation for a $0.12 \mathrm{~m}$ tall grass surface with a solar radiation reflectivity of 0.23 , and a stomatal resistance of $70 \mathrm{~s} / \mathrm{m}$ (Allen et al. 1998). The weather data used are monthly sunshine hours or solar radiation, mean maximum and minimum air temperature, and total precipitation. Mean wind speed at $2 \mathrm{~m}$ is assumed constant at $2 \mathrm{~m} / \mathrm{s}$ (this assumption has little effect on the calculations). Procedures for converting sunshine to solar radiation, and solar radiation and air temperature data to net radiation, can be found in Allen et al. (1998) and Spittlehouse (2003, 2004). Using solar radiation instead of sunshine hours gave virtually the same values for $\mathrm{E}_{\text {ref }}$. Normals were used for missing monthly sunshine hours. $\mathrm{E}_{\text {ref }}$ calculated using normals agrees with to within $5 \%$ of the average $\mathrm{E}_{\text {ref }}$ determined annually and then averaged over the period of the normals.

TABLE 3.4 Averages for 1970-2005 of annual values for weather stations listed in Table 3.3. Precipitation (PPT) as snow is for 1961-1990 for all stations except Upper Penticton Creek, which is 1992-2005.

\begin{tabular}{|c|c|c|c|c|c|c|c|}
\hline Location $^{\text {a }}$ & $\begin{array}{l}\text { Solar } \\
\text { radiation } \\
\left(\mathrm{MJ} / \mathrm{m}^{2}\right)\end{array}$ & $\begin{array}{l}\text { Maximum } \\
\mathrm{T}_{\text {air }}\left({ }^{\circ} \mathrm{C}\right)\end{array}$ & $\begin{array}{l}\text { Minimum } \\
\mathrm{T}_{\text {air }}\left({ }^{\circ} \mathrm{C}\right)\end{array}$ & $\begin{array}{l}\text { Average } \\
\mathbf{T}_{\text {air }}\left({ }^{\circ} \mathbf{C}\right)\end{array}$ & $\begin{array}{l}\text { Annual } \\
\text { PPT } \\
(\mathrm{mm})\end{array}$ & $\begin{array}{l}\text { May-Sept } \\
\text { PPT } \\
(\mathbf{m m})\end{array}$ & $\begin{array}{l}\text { PPT as } \\
\text { snow } \\
(\mathrm{mm})\end{array}$ \\
\hline Cranbrook A & 4712 & 11.7 & -0.1 & 5.8 & 382 & 199 & 148 \\
\hline Dease Lake A & 3474 & 5.0 & -6.5 & -0.7 & 426 & 248 & 227 \\
\hline Fort St John A & 3948 & 6.9 & -2.8 & 2.1 & 463 & 295 & 198 \\
\hline Kamloops A & 4490 & 14.5 & 3.4 & 9.0 & 279 & 144 & 86 \\
\hline Nanaimo A & 4255 & 14.8 & 4.9 & 9.9 & 1147 & 186 & 93 \\
\hline Penticton A & 4386 & 14.7 & 3.7 & 9.2 & 327 & 155 & 73 \\
\hline Upper Penticton Creek & 4438 & 7.4 & -3.6 & 1.9 & 700 & 305 & 320 \\
\hline Prince George A & 3942 & 9.4 & -1.4 & 4.0 & 597 & 293 & 234 \\
\hline Prince Rupert A & 3005 & 10.5 & 3.8 & 7.2 & 2576 & 789 & 143 \\
\hline Smithers A & 3598 & 9.2 & -1.2 & 4.0 & 510 & 228 & 216 \\
\hline Tofino A & 3994 & 12.9 & 5.4 & 9.2 & 3230 & 600 & 53 \\
\hline Victoria A & 4581 & 14.2 & 5.4 & 9.8 & 876 & 141 & 47 \\
\hline
\end{tabular}

a Locations with an "A" following the name indicate measurements made at airports 
other years. Calculating $\mathrm{E}_{\text {ref }}$ and CMD using climate normals misses this variability and also tends to underestimate the mid-summer values. The bulk of the CMD occurs during summer. The annual variation in $\mathrm{E}_{\mathrm{ref}}$ and CMD for May to September is shown in Figure 3.9 for Victoria Airport. In this warm, sunny, and dry environment, $\mathrm{E}_{\text {ref }}$ and CMD are high. Annual variability is mainly driven by the variation in precipitation. Two of the wettest and driest summers in the 35-year record have occurred in the last decade.

Figure 3.10 shows 105 years of climatic moisture deficits for the Campbell River Airport on the east coast of Vancouver Island (Spittlehouse 2004). The CMD varied from less than 100 to over $350 \mathrm{~mm}$. In the upper panel of Figure 3.10, higher than average CMD years are indicated by a positive value and lower than average by a negative value. A period with extremely high CMD occurred between the 1930 s and 1960. Occasionally, there are two consecutive very dry years (e.g., 1951 and 1952; 2002 and 2003). How this influences the vegetation will depend on the soil type and soil depth (Spittlehouse 2003). The between-year variation in CMD for Campbell River is similar to that for Victoria (Figure 3.9) because both are coastal sites on the lee side of Vancouver Island, about $250 \mathrm{~km}$ apart. The main difference is the higher CMD at Victoria, but differences in dryness between years also occur.

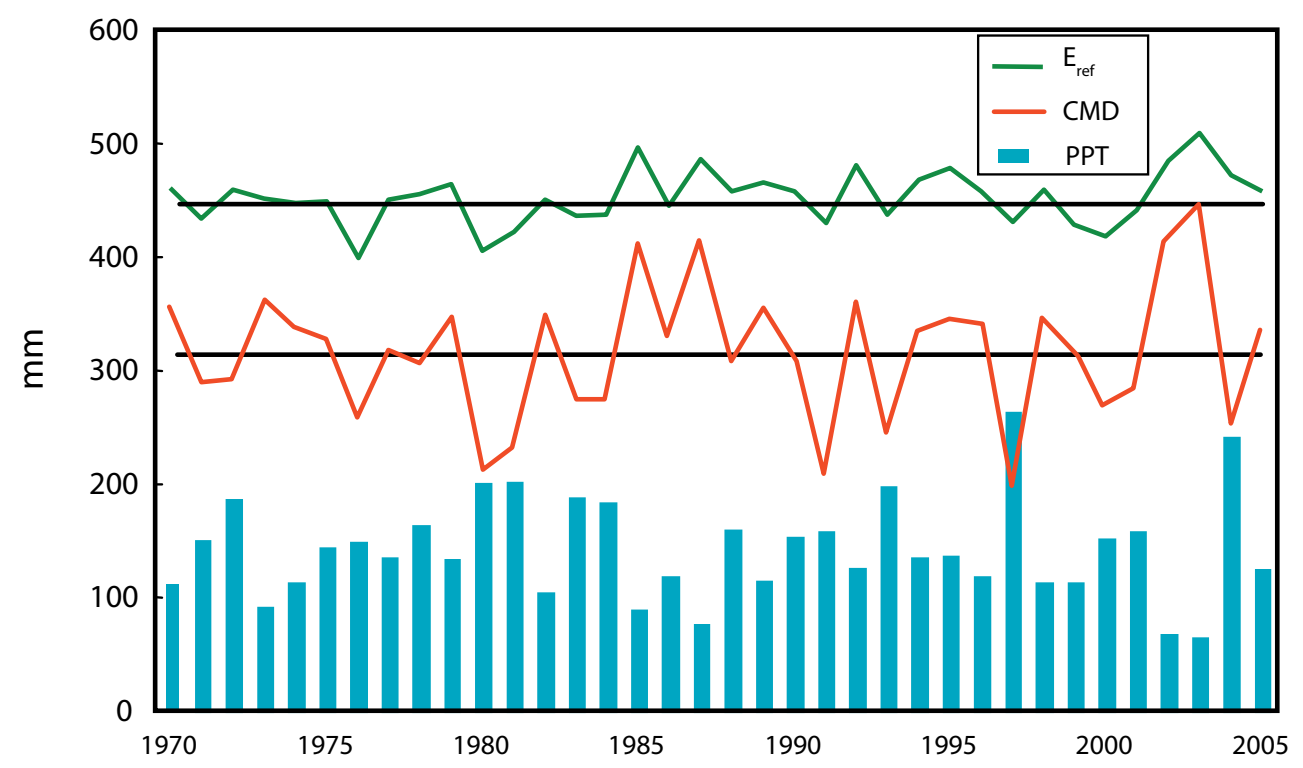

FIGURE 3.9 May to September reference evaporation (green solid line), climatic moisture deficit (red solid line), and total precipitation (blue bar) for Victoria Airport 1970-2005. The solid black lines show the mean for the period for $E_{\text {ref }}$ and CMD. More information on Victoria can be found in Tables 3.3 and 3.4. $E_{\text {ref }}$ was calculated using the Penman-Monteith equation. 

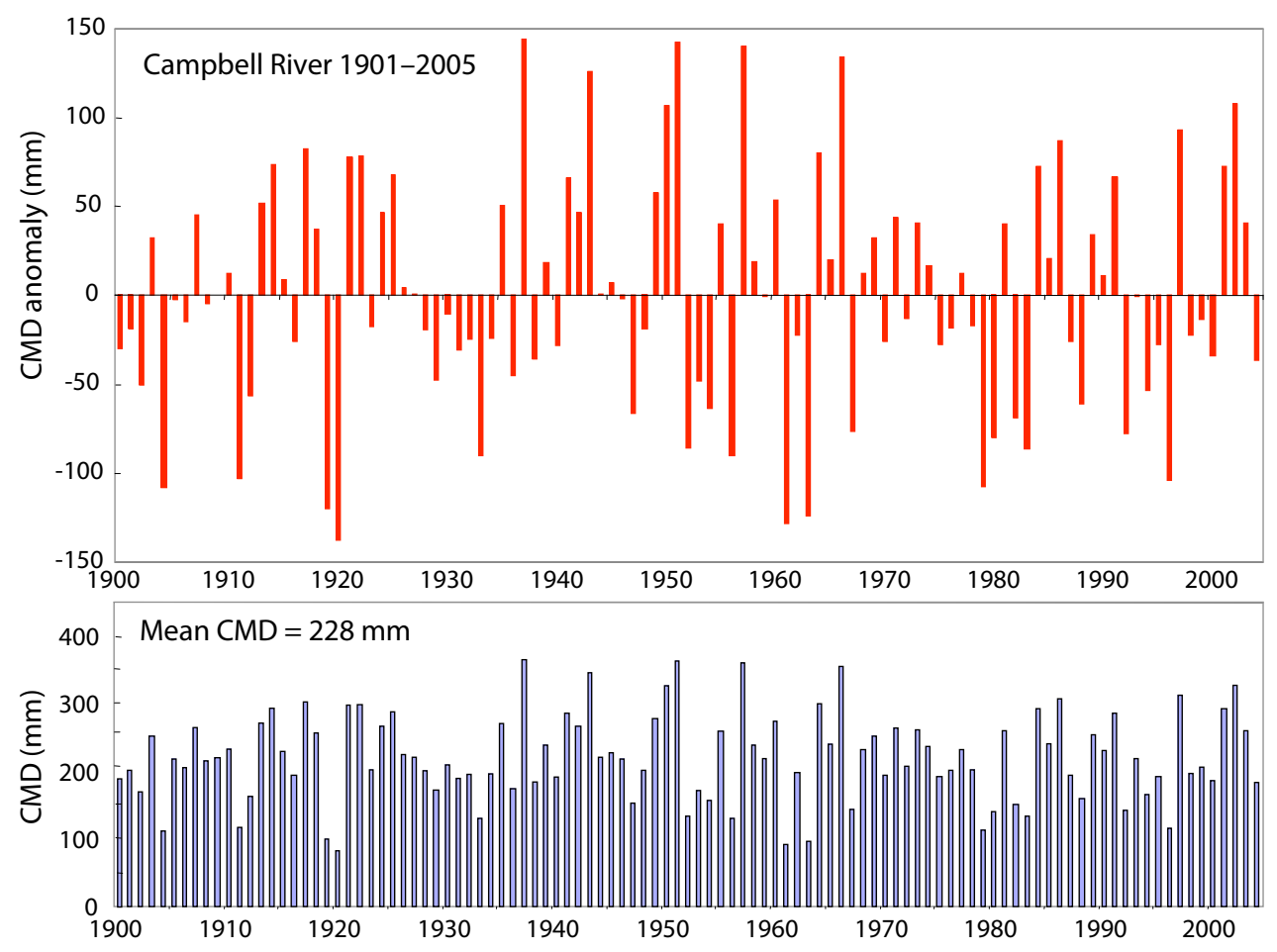

FIGURE 3.10 105 years of climate moisture deficits for the Campbell River airport. The lower panel shows the May to October climatic moisture deficit (CMD, $\mathrm{mm}$ ) for Campbell River Airport for 1901-2005. The upper panel shows the between-year variation in CMD (anomaly in $\mathrm{mm}$ ) obtained by subtracting the period mean CMD (228 $\mathrm{mm}$ ) from the annual values. Negative values indicate that the CMD was lower (wetter season) than the average and positive ones higher (drier season) than average. $E_{\text {ref }}$ was calculated using the Penman-Monteith equation.

\section{INFLUENCE OF ELEVATION}

Temperature tends to decrease with increasing elevation while precipitation increases; however, the vertical gradients vary in both space and time (e.g., Stahl et al. 2006c). Particularly in coastal regions, the variation of air temperature with elevation can influence whether precipitation falls as rain or snow. The relative influence of snow accumulation and melt on streamflow in coastal regions tends to increase with increasing basin elevation. For more details, see Chapter 4 ("Regional Hydrology").

Evaporative demand tends to decrease with elevation, which, combined with the positive relation between precipitation and elevation, results in a decrease in CMD with increasing elevation. This elevational dependence is illustrated with data for the east coast of Vancouver Island. Because of the lack of high-elevation weather stations in this area, temperature and precipitation data were determined from the high spatial resolution interpolation of climate data for British Columbia (Spittlehouse 2006; Wang et al. 2006). Mean monthly temperature and precipitation were determined at four separate elevations on the east side of central Vancouver Island: 100, 600, 1100 , and $1800 \mathrm{~m}$. The $100-\mathrm{m}$ values are equivalent to those for Campbell River Airport (106 m). Evaporative demand and CMD were calculated for each of the four elevations and summed to give annual totals (Table 3.5). Evaporative demand and CMD decrease with elevation as a function of a decrease in temperature and increase in precipitation. The high precipitation in coastal British Columbia from October through April restricts the CMD to summer. A CMD occurs from May to September at $100 \mathrm{~m}$ of elevation, June to August at 600 and $1100 \mathrm{~m}$, and July and August at $1800 \mathrm{~m}$. 
TABLE 3.5 Evaporative demand $\left(E_{\text {ref }}\right)$, climatic moisture deficit $(C M D)$, mean annual temperature $(M A T)$, and precipitation (MAP) at four elevations on the east coast of Vancouver Island near Campbell River. Evaporative demand for $1800 \mathrm{~m}$ is restricted to June to September because snow would be covering the vegetation outside of this period. Evaporation is assumed to occur in forests when the air temperature is above $0 \mathrm{C}^{\circ}$ even though there is snow on the ground below the canopy. Evaporative demand was calculated using temperature data and the Thornthwaite method (Thornthwaite 1948; Mather and Ambroziak 1986).

\begin{tabular}{lrrrr}
\hline Elevation $(\mathbf{m})$ & $\mathbf{1 0 0}$ & $\mathbf{6 0 0}$ & $\mathbf{1 1 0 0}$ & $\mathbf{1 8 0 0}$ \\
\hline $\mathrm{E}_{\text {ref }}(\mathrm{mm})$ & 605 & 555 & 495 & 340 \\
$\mathrm{CMD}(\mathrm{mm})$ & 200 & 135 & 95 & 55 \\
MAT $\left({ }^{\circ} \mathrm{C}\right)$ & 8.4 & 6.9 & 5.1 & 2.0 \\
MAP $(\mathrm{mm})$ & 1450 & 1860 & 2180 & 2590 \\
\hline
\end{tabular}

INFLUENCE OF SYNOPTIC-SCALE CIRCULATION

The synoptic-scale circulation types are characterized by distinctive surface climate anomalies, which can vary seasonally. Figure 3.11 illustrates these anomalies for selected synoptic types. A positive anomaly indicates that conditions associated with a given synoptic type are wetter (for precipitation) or warmer (for air temperature) than the overall average for a given location. In Type 1, a ridge of high pressure results in relatively dry conditions over southern British Columbia, while northern British Columbia tends to be warmer than average because of the advection of maritime air via the southwesterly Pacific airflow. Type 6 is typical of an arctic outbreak, in which a high-pressure system extends south from the Yukon, accompanied by the movement of cold, dry arctic air over most of the province. The cold, dense air is confined by the topographic barriers of the Coast Mountains and Rocky Mountains, with cold air drainage through deep coastal valleys resulting in cold, windy condi- tions at coastal sites. Temperature anomalies associated with Type 6 are strongly negative throughout the province, and precipitation also tends to be lower than average. Type 12 is dominated by a lowpressure cell in the Gulf of Alaska, which brings a strong southwesterly flow of warm moist air over southern British Columbia, resulting in warm, wet conditions. The source of the air mass is the tropical Pacific Ocean, and extreme versions of this pattern are called a "pineapple express" or "tropical punch." Type 13 has a low-pressure cell located southeast of the Gulf of Alaska, in conjunction with a ridge of high pressure extending into British Columbia from the south. This pattern results in strong southerly airflow along the Coast, with generally warmer than average conditions throughout most of British Columbia. The southerly airflow brings wet conditions to coastal areas, but the high-pressure ridge suppresses precipitation in the Interior. 
MSLP composite

Type 1

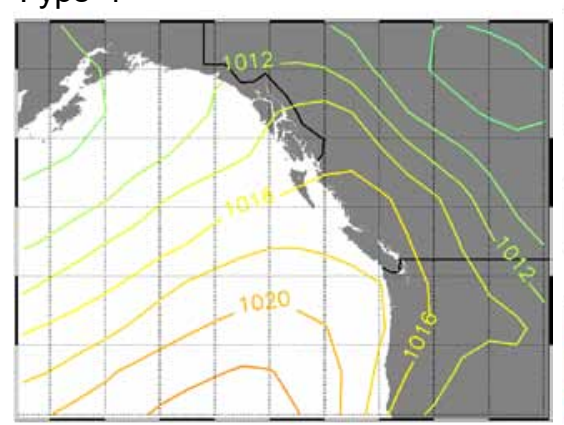

Type 6

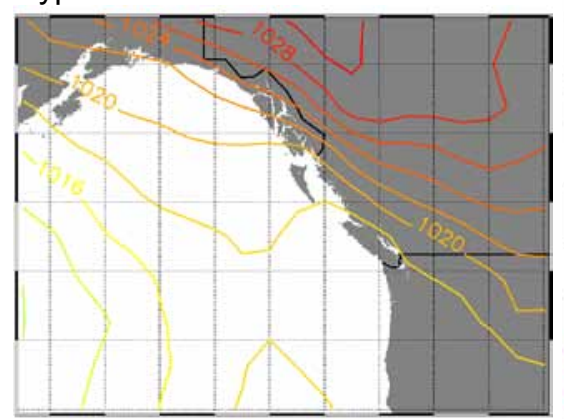

Type 12

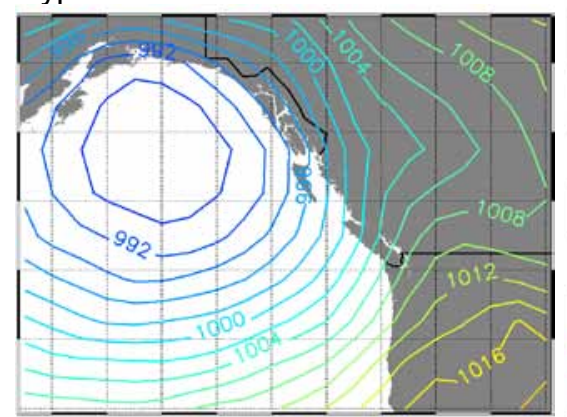

Type 13

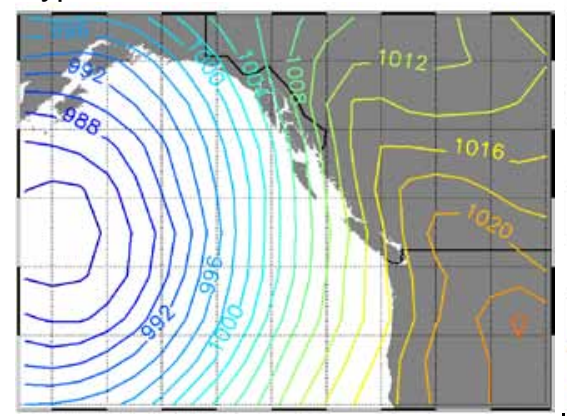

Temperature Anomaly

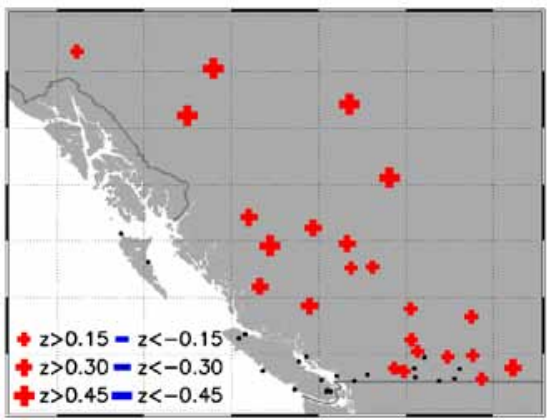

$z>0.45=z<-0.45$

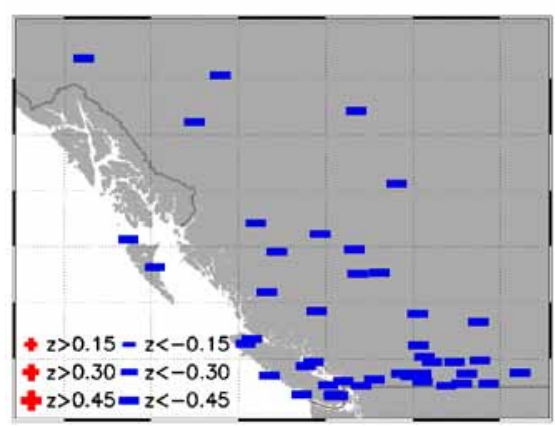

$4 z>0.45=z<-0.45$

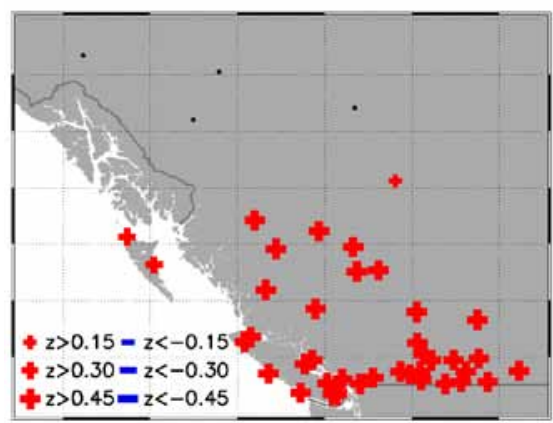

$4 z>0.45=z<-0.45$

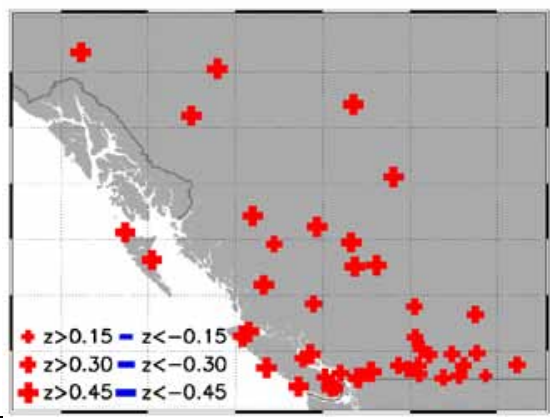

Precipitation Anomaly
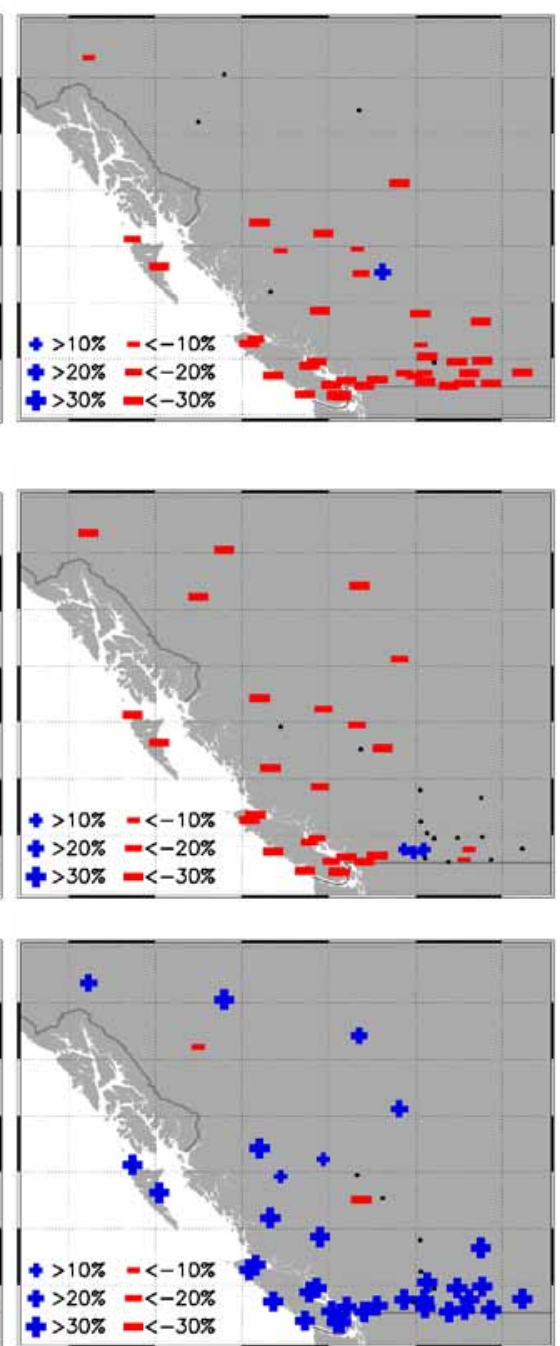

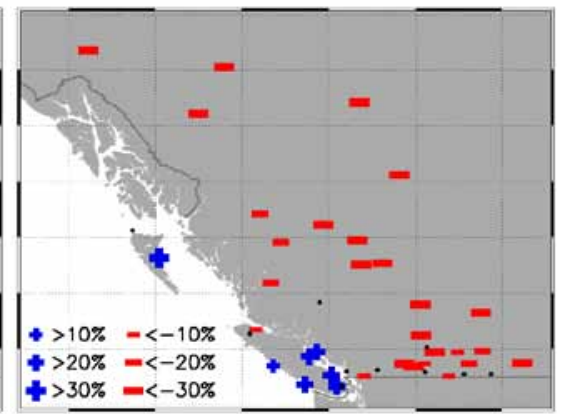

FIGURE 3.11 Winter (December to February) surface climate anomalies associated with selected synoptic types. (Adapted from Stahl et al. 2006b) 
Sea surface temperatures and atmospheric circulation patterns over the Pacific Ocean strongly influence the weather and climate of British Columbia. These large-scale phenomena are often called "teleconnections," in reference to the correlation of climatic phenomena over large distances. For example, sea surface temperatures in the equatorial Pacific Ocean influence weather and climate throughout large parts of North America, including much of western Canada. The dominant modes of atmosphere-ocean variability relevant to British Columbia include El Niño-Southern Oscillation (ENSO), Pacific Decadal Oscillation (PDO), Pacific North American (PNA) Pattern, and Arctic Oscillation (AO).

\section{El Niño-Southern Oscillation}

El Niño events (also known as ENso warm phase) are characterized by a warming of the equatorial ocean surface off the coast of South America. La
Niña conditions (ENSO cool phase) involve upwelling of cold water in the same region (Figure 3.12). The ENSO is a coupled phenomenon in which the sea surface temperatures in the tropical Pacific set up the atmospheric circulation and surface winds, which in turn determine the sea surface temperatures, so that positive feedbacks are strong. However, changes below the ocean surface, and the slow response of the ocean off the equator, provide a delayed signal that can reverse the changes and cause the oscillation from El Niño to La Niña (Trenberth 1997). El Niño winters favour a split in the jet stream in the mid-Pacific to produce both low-latitude and high-latitude storm tracks that avoid southern British Columbia (Shabbar et al. 1997). In British Columbia, winters following the onset of an El Niño event are generally warmer and drier than normal, and La Niña winters are generally cooler and wetter (Shabbar and Khandekar 1996; Shabbar et al. 1997; Stahl et al. 2006b) (Figure 3.13).

\section{El Niño Southern Oscillation}
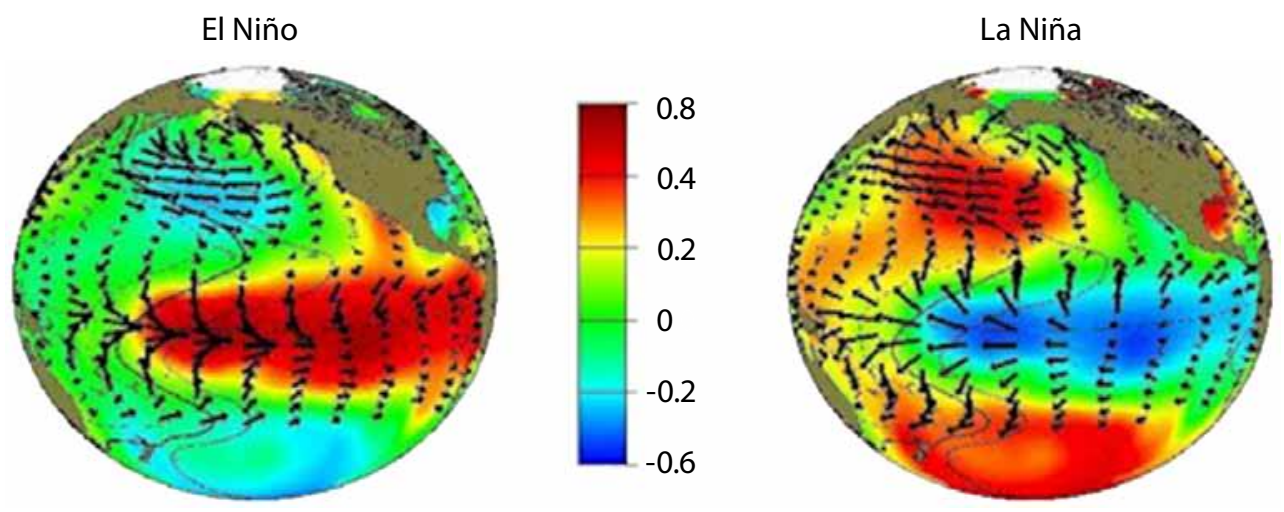

FIGURE 3.12 Sea surface temperature and surface wind stress anomalies (differences from long-term average) during El Niño and La Niña conditions. Colours indicate magnitude of temperature anomalies; length and direction of arrows indicate wind stress magnitude and direction. (www.wrh.noaa.gov/fgz/science/pdo.php) 

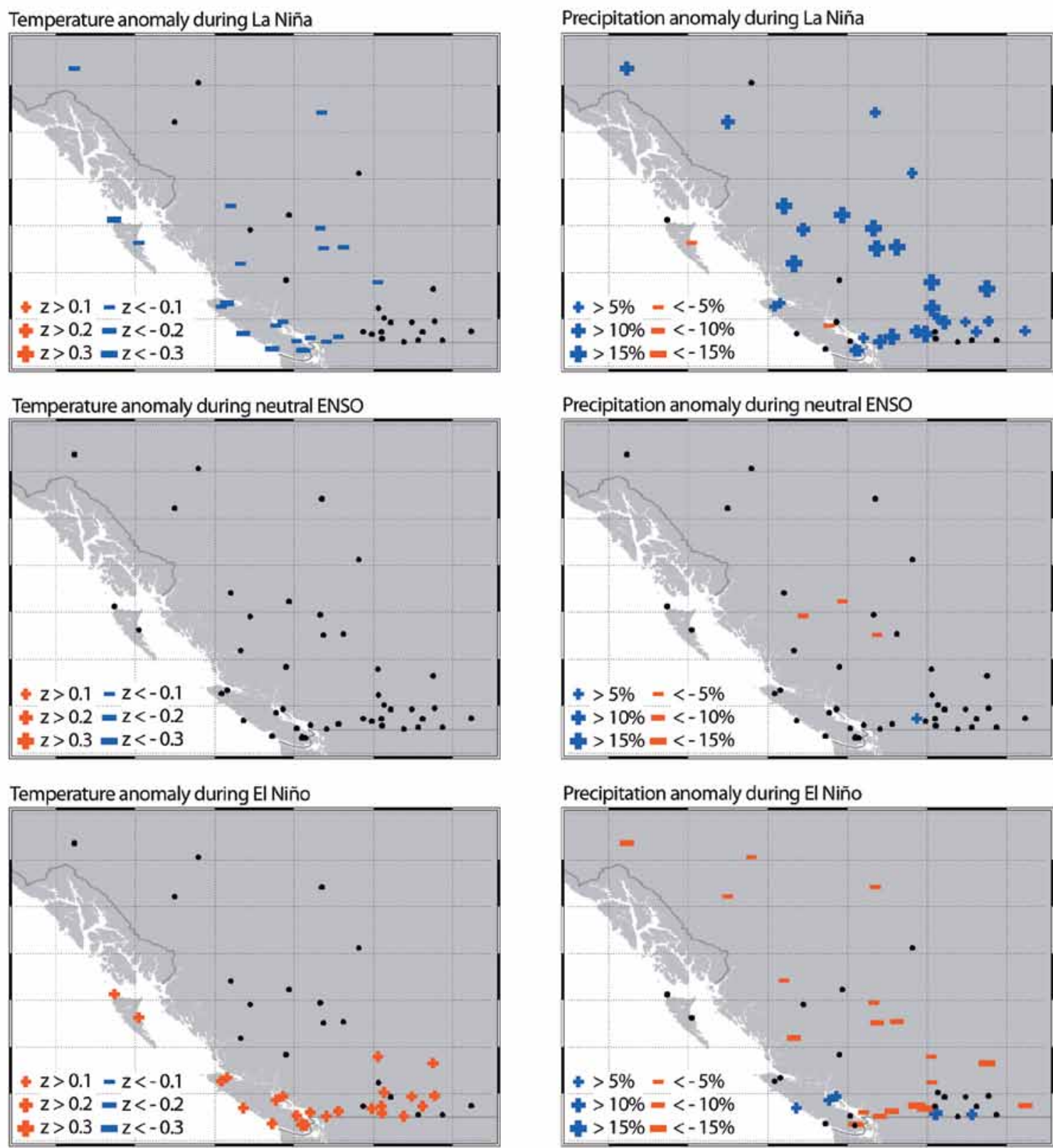

FIGURE 3.13 Winter (December to February) temperature and precipitation anomalies associated with ENSO cool (La Niña), neutral, and warm (EI Niño) phases. Temperature anomalies are z-scores (i.e., standardized by dividing by the standard deviation of the anomalies); precipitation anomalies are percentage of the long-term average (adapted from Stahl et al. 2006b).

\section{Pacific Decadal Oscillation}

The Pacific Decadal Oscillation (PDO) involves shifts between two dominant patterns of sea surface temperatures in the North Pacific Ocean (Mantua et al. 1997). The warm (positive) phase of the PDO is characterized by below-normal sea surface temperatures in the central and western north Pacific and unusually high ones along the west coast of North America (Figure 3.14). The PDO cold (negative) phase produces the reverse distribution. Positive PDO phases are associated with positive winter temperature anomalies throughout western Canada and with negative precipitation anomalies in the mountains and interior, which also reduce the snowpack (Figure 3.15). Temperature impacts over Canada tend to be 


\section{Pacific Decadal Oscillation}
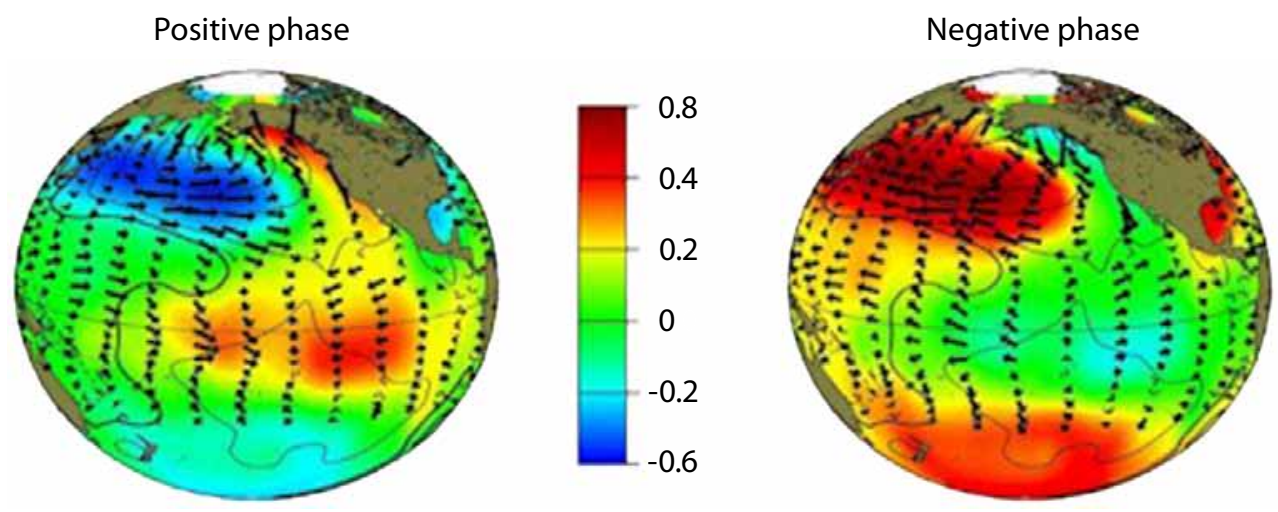

FIGURE 3.14 Sea surface temperature and surface wind stress anomalies (differences from long-term average) during positive and negative phases of the PDO. Colours indicate magnitude of temperature anomalies; length and direction of arrows indicate wind speed and direction. (www.wrh.noaa.gov/fgz/science/pdo.php)

enhanced when ENSO and PDO are in phase (Bonsal et al. 2001a). El Niño and positive PDo winters are characterized by a deepening of the Aleutian Low and an enhanced high-pressure ridge over the Rocky Mountains. This situation represents a positive Pacific North American pattern and indicates a northward displacement of the polar jet stream, which inhibits the outflow of cold arctic air, and thus accounts for the positive temperature anomalies (Bonsal et al. 2001a). During negative PDo phases, the jet stream is displaced southward, which results in more frequent arctic outflow events and hence lower temperatures.

The PDO is often described as a long-lived El Niño-like pattern of Pacific climate variability, but two main characteristics distinguish the PDo from the ENSO: (1) 2oth-century PDO "events" persisted for 20-30 years, while typical ENSO events persist for 6-18 months; and (2) the climatic fingerprints of the PDO are most visible in the north Pacific / North American sector, while secondary signatures exist in the tropics. The opposite is true for ENSo (Mantua et al. 1997). Only two full PDo cycles appear to have occurred in the past century: "cool" PDO regimes prevailed from 1890 to 1924 and again from 1947 to 1976, while "warm" PDo regimes dominated from 1925 to 1946 and from 1977 through (at least) the mid1990s (Hare and Mantua 2000). In British Columbia, PDO cool and warm phases are associated with temperature and precipitation anomalies that are similar to the corresponding ENSO phases (Figures 3.13 and
3.15) (Fleming 2006; Fleming et al. 2007). The PDO is not fully understood, and it is not possible to predict when shifts will occur. Despite this limitation, the state of the PDO may be used to improve season-toseason and year-to-year climate forecasts for North America because of its strong tendency for multiseason and multi-year persistence. Recognition of the PDO is important because it shows that "normal" climate conditions can vary over time periods comparable to the length of a human's lifetime.

\section{Pacific North American Pattern}

The Pacific North American (PNA) pattern is a natural, internal mode of atmospheric circulation variability over the North Pacific and North America. The strong or enhanced (positive) phase is characterized by a strong Aleutian Low, with southerly airflow along the west coast of North America and a ridge of high pressure over the Rocky Mountains. The weak (negative) phase is dominated by a weaker Aleutian Low and westerly, zonal flow. The strong phase tends to coincide with warmer winters and reduced snowpack accumulation throughout British Columbia, especially in the southern Coast Mountains (Moore 1996; Moore and McKendry 1996). Although both enhanced and weak PNA patterns can occur under any sea surface temperature conditions, positive values of the PNA pattern tend to be associated with the warm (positive) phase of PDO and El Niño events (Hsieh and Tang 2001). 
Temperature anomaly during negative PDO

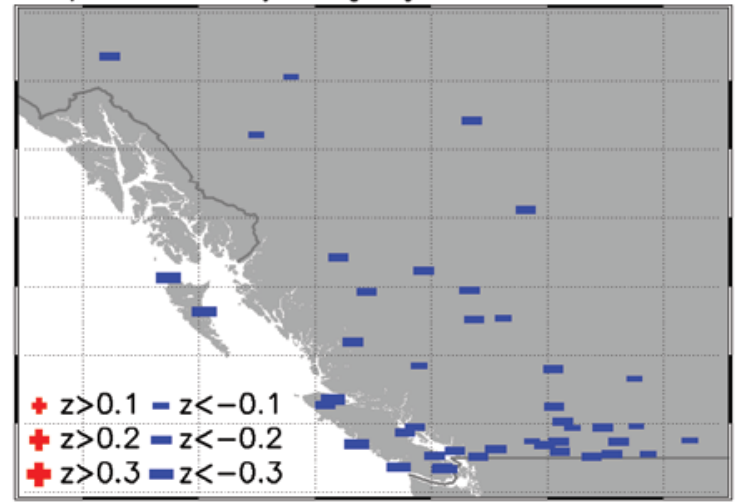

Temperature anomaly during neutrol PDO

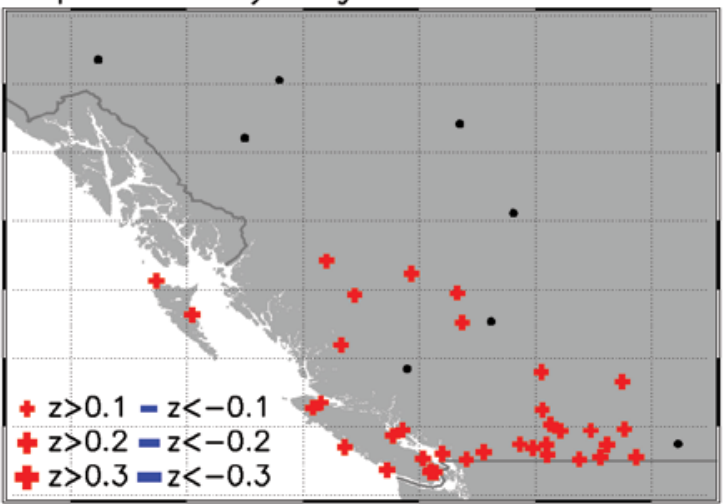

Temperature anomaly during positive PDO

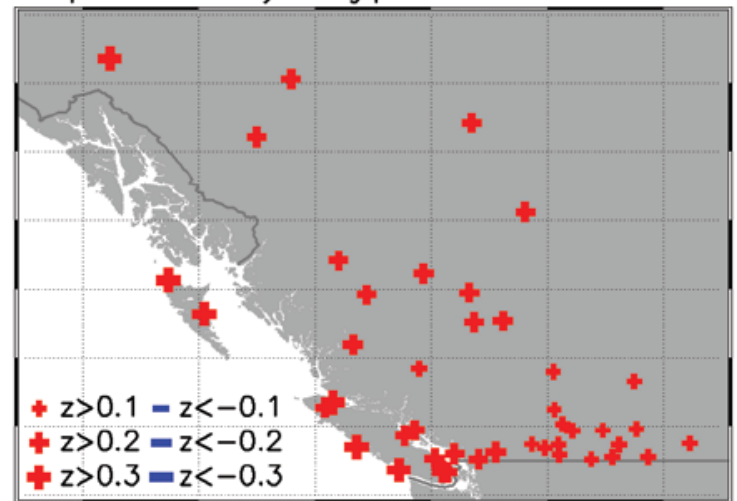

Precipitation onomaly during negative PDO

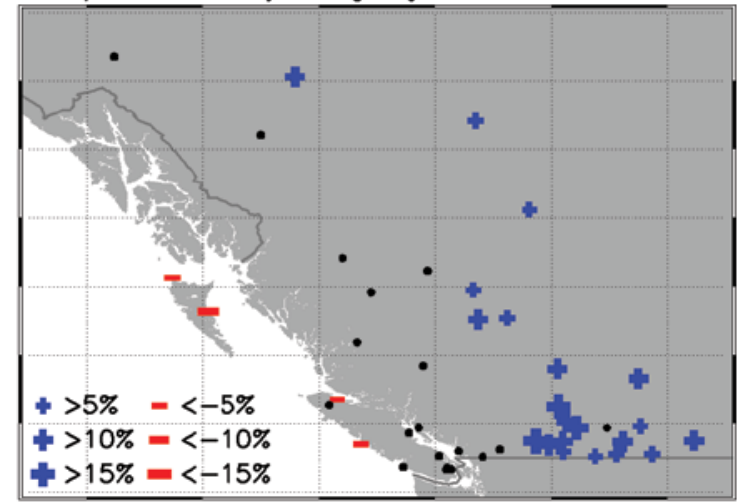

Precipitation onomaly during neutral PDO

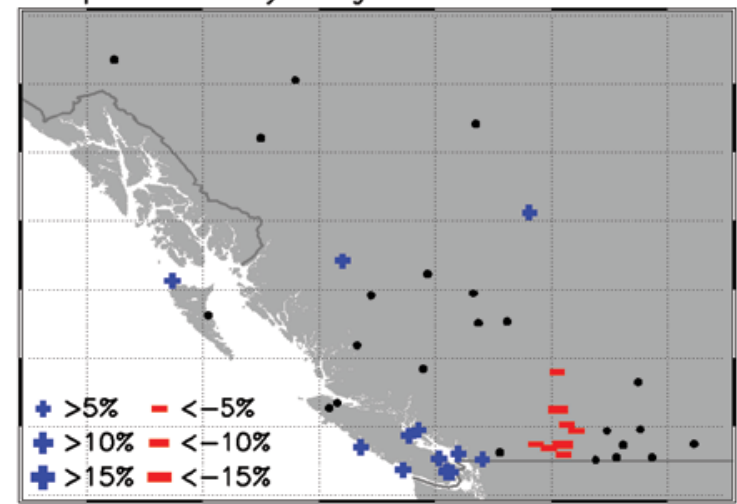

Precipitation onomaly during positive PDO

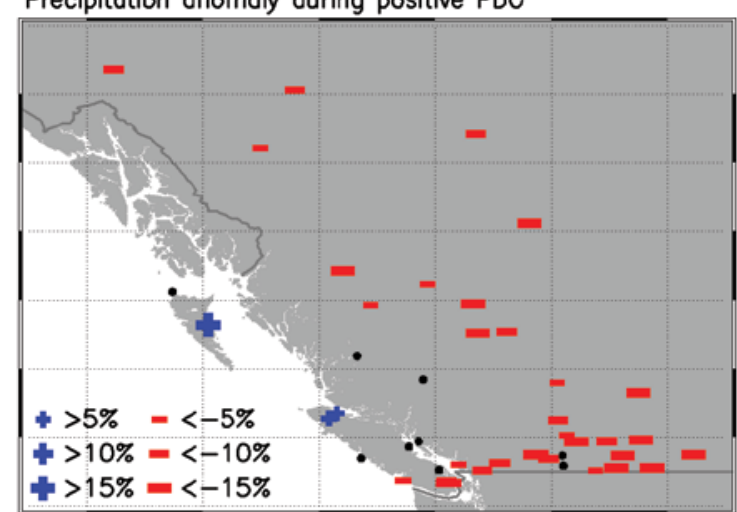

FIGURE 3.15 Winter (December to February) temperature and precipitation anomalies associated with PDO cool, neutral, and warm phases (after Stahl et al. 2006b). Temperature anomalies are z-scores (i.e., standardized by dividing by the standard deviation of the anomalies); precipitation anomalies are percentage of the long-term average.

Variations in climatic patterns associated with the ENSO, PDO, and PNA tend to be strongest in winter; however, some effects, such as increased air temperature associated with ENSO/PDO warm phase, can extend into spring and early summer (Fleming 2006; Fleming et al. 2007).

\section{Arctic Oscillation}

The Arctic Oscillation (AO) is associated with fluctuations in the strength of the winter stratospheric polar jet. A positive AO index value generally indicates negative and positive sea-level pressure 
anomalies in the Arctic and mid-latitudes, respectively, and relatively strong $55^{\circ} \mathrm{N}$ (surface) westerlies; a negative index value indicates the opposite pressure anomalies and weaker westerly flow (Thompson and Wallace 1998). Some evidence indicates that the negative AO phase is linked to the occurrence of extreme cold-weather systems (arctic outbreaks) that can cause mountain pine beetle mortality. For example, the arctic outbreak events in autumn 1984 and autumn 1985 appear to have ended the Chilcotin beetle outbreak that began in the late 1970s (Stahl et al. 2006a).

The synoptic climatology presented earlier provides an intuitive framework for understanding the influence of large-scale teleconnections on the surface climate of British Columbia. For exam- ple, synoptic types associated with warmer winter weather, such as types 10,12, and 13, tend to be more frequent in warm-phase ENSO and PDO conditions (Stahl et al. 2006b). In addition, for some synoptic types, weather conditions at some stations exhibit systematic within-type variability among phases. For example, in warm-phase PDo years, not only are synoptic types associated with arctic outbreaks less frequent, but the minimum air temperatures tend not to be so extreme even when those types do occur. The combination of these effects suggests that air temperatures low enough to cause cold-mortality of the mountain pine beetle are less likely to occur in warm-phase PDO and warm-phase ENSO years (Stahl et al. 2006a).

\section{EXTREME EVENTS}

The hydrogeomorphology of catchments is affected not only by the regional climate, which represents the collective effect of multiple weather systems, but also by singular events, such as rainfall or snowmelt events of sufficient intensity and duration to generate floods, slope failures, or widespread surface erosion. Along the coast, hydrogeomorphically significant events often occur under synoptic situations similar to Type 12 (Figures 3.1 and 3.16). The southwesterly airflow advects large quantities of warm, humid air from the tropical Pacific region, creating intense rainfall along the entire coast, which can also penetrate inland to some extent. Such events have been called a "pineapple express" or "tropical punch." For example, a "pineapple express" in October 2003 generated significant flooding and landslide activity all along the Coast Mountains (Jakob et al. 2006). ${ }^{1}$

Extreme winds often accompany extreme precipitation events. Wet soils result in reduced soil-root adhesion and soil shear strength and, combined with extended periods of very strong winds, can cause extensive damage through blowdown of trees, which can then trigger landslides. Snow and ice on the crown also increase the risk of stem breakage and windthrow (Stathers et al. 1994). Extreme winds are associated with the passage of frontal storms originating in the Pacific Ocean, and occur most frequently in the winter. Strong winds can also ac- company summer thunderstorms, which are more likely to occur in the Interior than on the Coast. Local terrain can direct airflow and increase wind speed; areas where valleys converge can experience extremely strong winds. Cutblock boundaries such as the edge of riparian reserves can be highly susceptible to blowdown.

The role of antecedent conditions complicates the definition of hydroclimatic thresholds for landslide initiation or flooding. For example, rainfall events are more likely to generate landslides and floods when soils are already moist (Toews 1991; Jakob and Weatherly 2003). In addition, "rain-on-snow" events occur when heavy rain in conjunction with warm air occurs in the presence of accumulated snow on the ground. Melting of the snowpack can augment rainfall and generate widespread landslides and (or) flooding. Egginton (2005) found that a range of conditions generated major landslides in northern British Columbia, including large cyclonic events and convective rainfall during summer. Mass-wasting events are often generated by intense, localized cells of rainfall that are not recorded by a climate station (e.g., Church and Miles 1987). Egginton (2005) found satellite images useful to help identify locations of heavy rainfall in the interpretation of landslide triggers in northern British Columbia. Landslides and their causal factors are discussed in detail in Chap-

1 McCollor, D. 2003. Summary of weather for the heavy rain event of 15 October through 23 October, 2003. BC Hydro, 27 Oct. 2003. Unpubl. internal memo. 


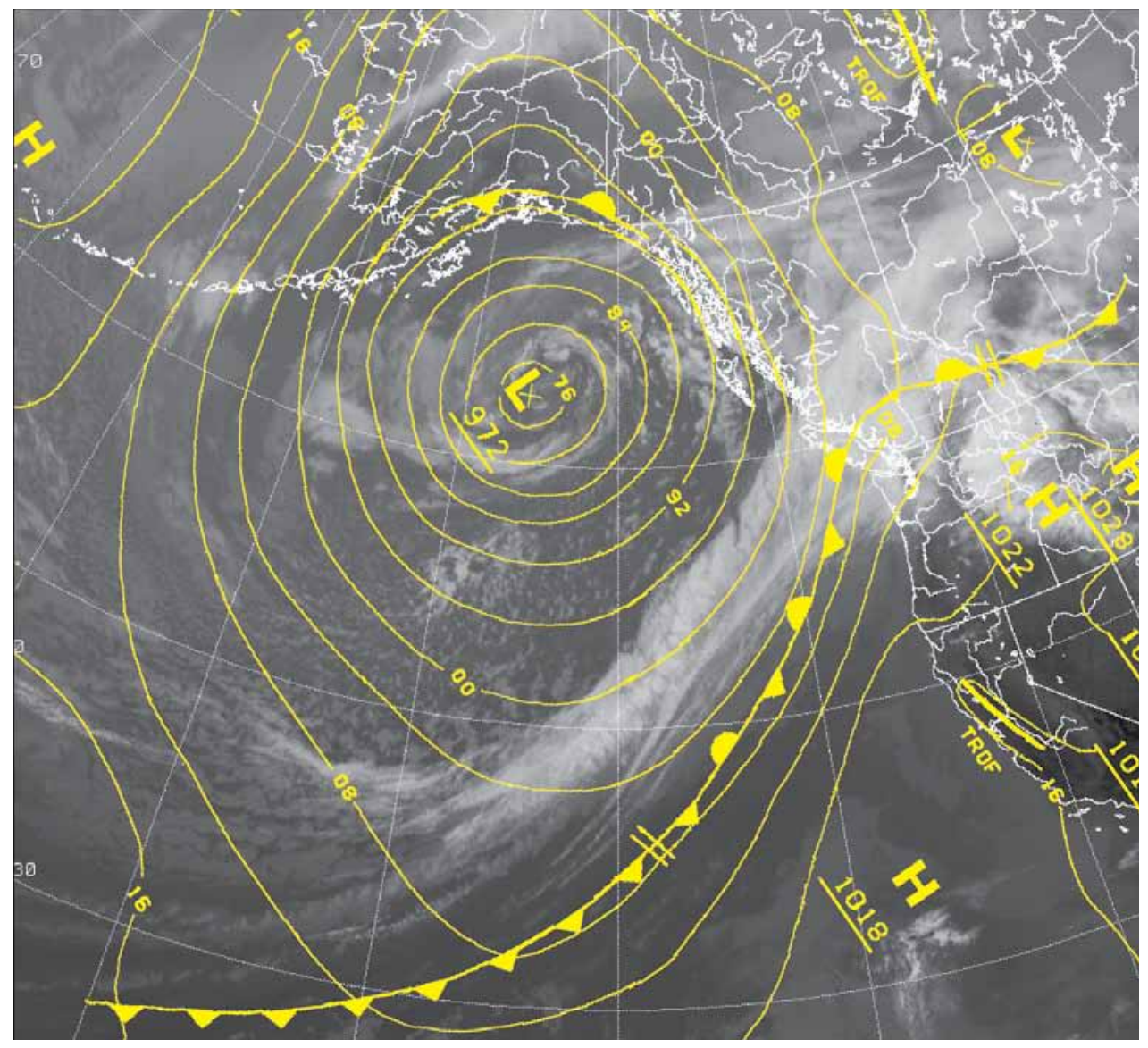

FIGURE 3.16 Depictions of the October 2003 "pineapple express" event that caused widespread flooding and mass-wasting events throughout coastal British Columbia. Weather map showing sea-level pressure isobars and fronts has been overlaid on a GOES satellite image showing pattern of water vapour. (Figure by Eric Leinberger)

ter 8, "Hillslope Processes," and Chapter 9, "Forest Management Effects on Hillslope Processes."

Droughts can be considered another form of extreme event. Extended periods of well below normal precipitation, either as winter snow or summer rain, can result in low streamflow with implications for water supply and fish habitat. Low summer flows and high summer air temperatures can produce high stream temperatures (Moore et al. 2005). Extremely high summer temperatures along with low precipitation also increase the risk of forest fires. This, in turn, has implications for water quality and streamflow through the increased risk of surface erosion and landslides because of the loss of ground cover, hydrophobicity of soils, and the effects on snow accumulation and melt.
Finally, extreme minimum temperatures, or the lack of them, can have indirect hydrologic implications. The prime example in British Columbia is the current mountain pine beetle infestation, which is partially caused by a lack of cold conditions late in the fall that would kill the insect. Stahl et al. (2006a) showed that mild winters and a decreased frequency of cold mortality for the pine beetles are associated with El Niño and PDO warm-phase conditions, but a decrease in extreme winter cold weather is also consistent with projected effects of climate warming. The reduction in transpiration and precipitation interception associated with tree mortality can increase soil moisture and water to streams (Hélie et al. 2005). 


\section{Climatic Variability and Change: Nature and Detection}

Climatic variability and change occur on a range of time scales. In addition to apparently random variability from year to year, systematic variations relate to phenomena such as the ENSO and PDO because of their coherent influences on air temperature and precipitation patterns (Figures 3.13 and 3.15). For example, there was a notable shift from dominantly negative PDO/PNA from about 1947 to 1976 , to dominantly positive PDO/PNA from 1977 into the late 1990s (Figure 3.17). This apparent step change shows up in many hydroclimatic records in southern British Columbia, including surface climate and snow accumulation (Moore and McKendry 1996; Fleming et al. 2007), streamflow (Moore 1991, 1996; Fleming et al. 2007), and glacier mass balance (Moore and Demuth 2001).

Of increasing concern are climatic changes over longer time scales and the attendant consequences for water resources. Scientific consensus has been building over the last two decades that global climate is currently undergoing an accelerated warming, largely caused by anthropogenic greenhouse gas emissions (Intergovernmental Panel on Climate Change 2007). Concern is growing about the effects of global change on regional and local climates and the consequences of these effects for terrestrial ecosystems, hydrology, and freshwater ecosystems. Climate change and the effects on watershed processes are discussed in detail in Chapter 19 ("Climate Change Effects on Watershed Processes in British Columbia").

The last major ice age ended roughly 10 ooo years ago, and since then the global climate has experienced both warm and cool periods (Rosenberg et al. 2004). The last global cool period, the "Little Ice Age," ended in the mid-19th century. Although instrumental climate records (e.g., temperature and precipitation measurements) in British Columbia mainly cover the most recent century or so, the Little Ice Age is recorded in proxy climate records, such as tree rings and glacier terminal moraines,

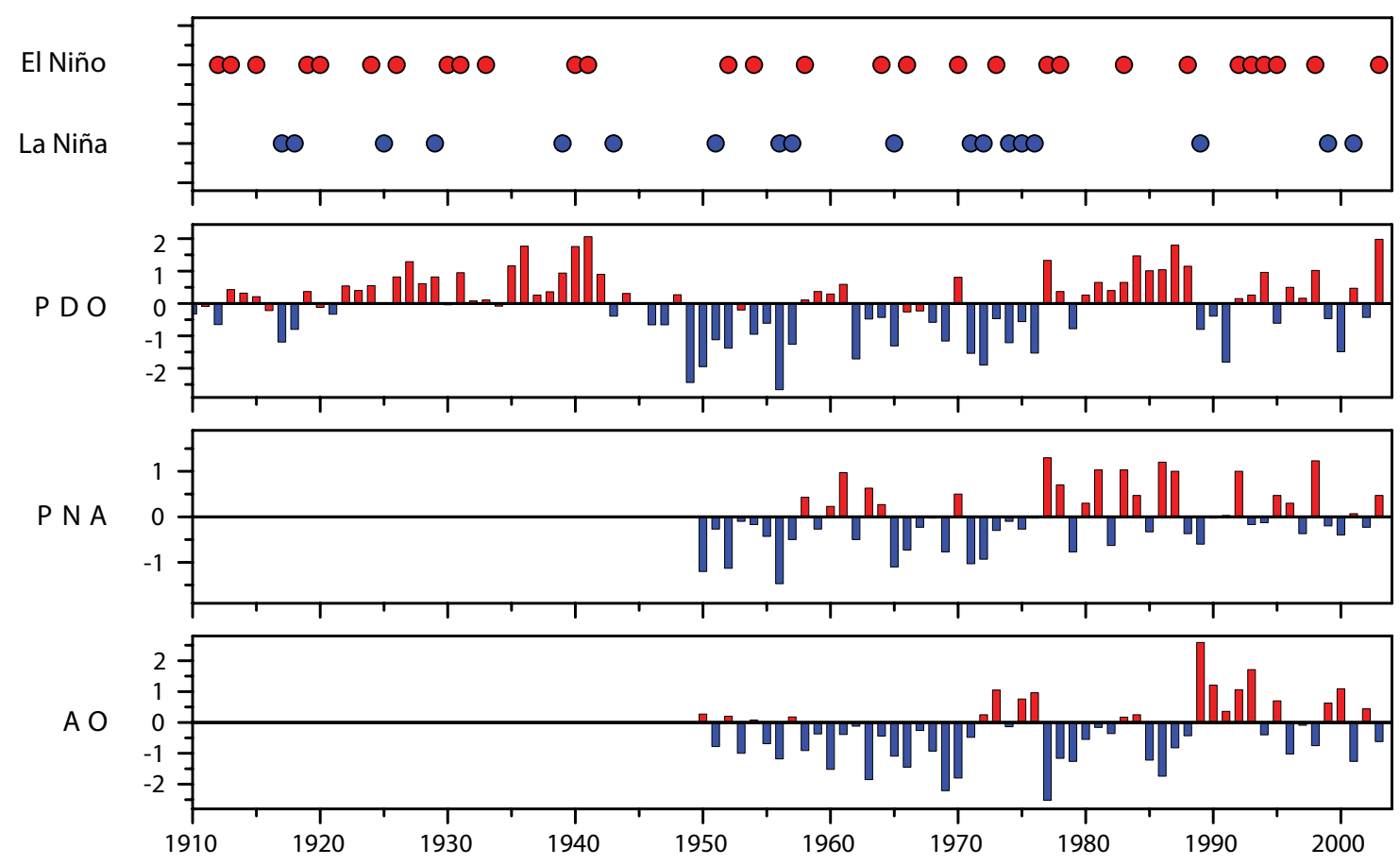

FIGURE 3.17 Time series of large-scale climatic indices. (www.wrcc.dri.edu/enso/ensodef.html) 
which clearly show that significant glacier retreat has occurred (B.C. Ministry of Water, Land and Air Protection 2002; also see Chapter 2). Substantial effort has identified recent trends in the instrumental climate record. Work has also focussed on the use of general circulation models (also increasingly known as "global climate models") to simulate future climate under different assumptions regarding greenhouse gas emissions and land use (Intergovernmental Panel on Climate Change 2007).

Resolving climatic changes within the instrumental climate record requires data at a temporal resolution that is appropriate to the spatial domain of interest (Zwiers and Zhang 2003). At a global scale, it may be appropriate to examine time series of annual mean temperatures. Annual means, however, are not as relevant when the interest is in regional impacts, where changes at seasonal and sub-seasonal scales can be important for ecological and hydrological processes. For example, even monthly data may be too coarse to detect changes in air temperature that can influence the onset and timing of snowmelt (Whitfield 2001).

Trend detection is strongly affected by the length of the record, the magnitude of the trend relative to inherent between-year variability, and the window of data relative to decadal shifts such as the PDO. For example, a station with data spanning the period 1920-1965 could have an apparent trend dominated by the shift from negative to positive PDO about 1947. If the record for the same station spanned the period 1960-1995, the apparent trend computed from the data might reflect the shift from negative to positive PDO in 1976-1977. For more details on climate variability and trends see Chapter 19 ("Climate Change Effects on Watershed Processes in British Columbia").

\section{Past Climatic Variability and Change in British Columbia}

A range of studies has looked for climatic trends in British Columbia, often in the context of specific locations or regions, or for specific climatic signatures. For example, Egginton (2005) examined climatic trends in northern British Columbia, particularly in relation to mass wasting, and Stahl et al. (2006a) focussed on the occurrence of winter temperatures low enough to cause mortality of mountain pine beetle. The general consensus from these studies is that British Columbia has been warming over the period of record, consistent with the current trend to increasing global temperatures. Vincent and Mekis (2006) found general trends across Canada, and particularly in southern British Columbia, to less extreme cold temperatures and more extreme warm temperatures. Regional variability, however, is significant in the magnitudes of trends, and the seasonal expression of these trends, which limits our ability to generalize at the provincial scale. For example, Bonsal et al. (2001b), Whitfield and Cannon (2000a, 200ob) and Whitfield et al. (2002a) found trends across southern British Columbia to significantly warmer springs, falls, and winters, but not summers. The pattern in northern British Columbia is different, with cooler falls and warmer winters. Variability also exists among studies. For example, Egginton (2005) found warming trends during fall in northern British Columbia. These differences among studies arise from the use of different periods of records, different methods of analysis (e.g., simple linear regression with time, Mann-Kendall non-parametric trend test), and differences in delineating regions.

Zhang et al. (2000) found that precipitation in western Canada increased by 5-35\% from 1950 to 1998. Whitfield et al. (2002b) showed that in southern British Columbia the winter wet periods were now more wet; early fall has become somewhat drier and late fall wetter. In northern British Columbia, in contrast, falls and early summers have become wetter.

Figures 3.18-3.20 illustrate trends in daily minimum and maximum air temperature and precipitation for the period 1900-2003, based on gridded estimates of climate data. The warming trend is stronger for daily minimum than daily maximum air temperatures, and is strongest in winter. Precipitation generally increased over the province in most seasons except autumn, for which the south coastal region tended toward decreasing precipitation, though the trends are not statistically significant. Figures 3.21 and 3.22 provide results from a trend analysis focussed on the period 1950-2003 that used station data rather than gridded values. These analyses suggest that the warming trend has been particularly expressed through a reduction in the frequency of cold nights, and to a lesser extent an increased frequency of warm days. For more details on climate variability and trends see Chapter 19 ("Climate Change Effects on Watershed Processes in British Columbia”). 


\section{Winter}

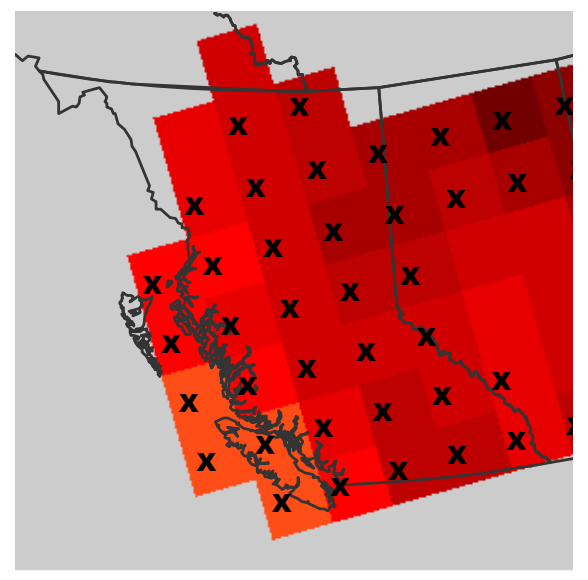

Summer

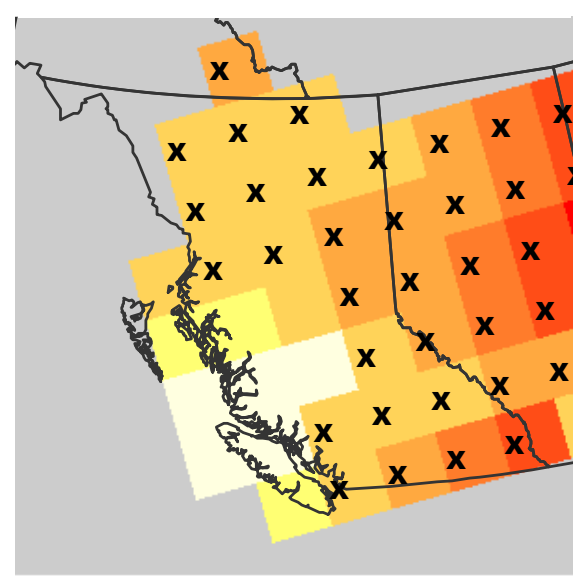

Annual

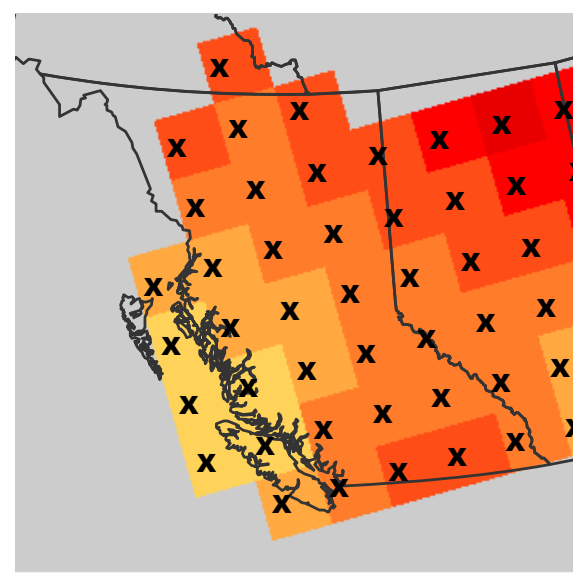

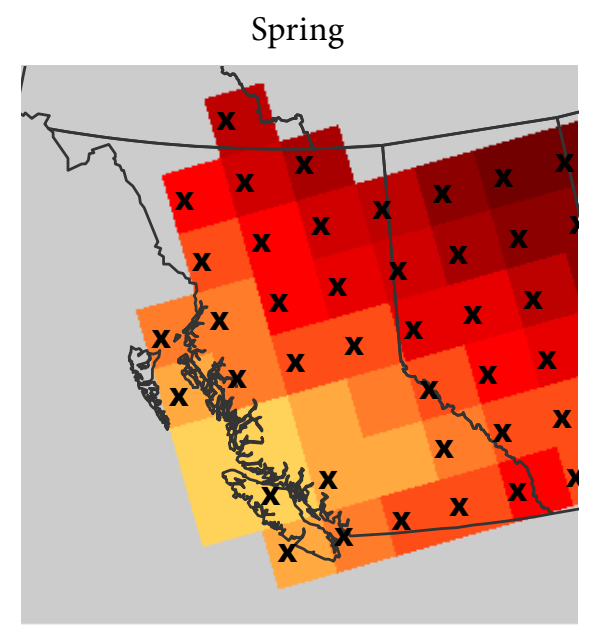

Fall

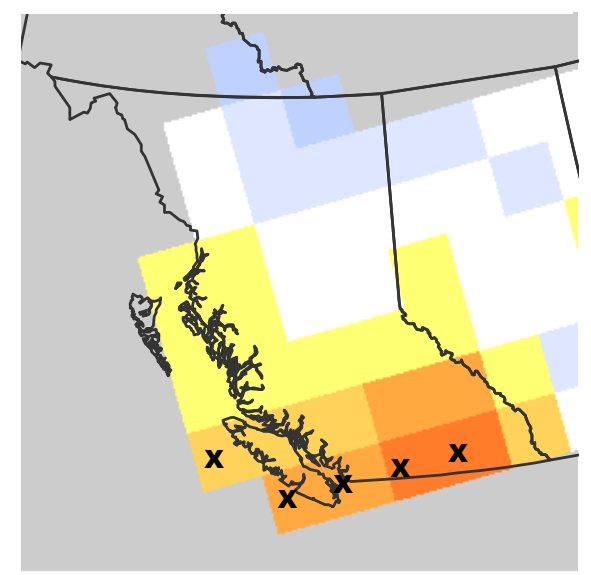

FIGURE 3.18 Trends in daily minimum air temperature for the period 1900-2003 for western Canada. Units are degrees Celsius over the 104-year period. Grid cells with crosses indicate trends that are significant at a 5\% significance level. Grey cells indicate areas with insufficient data to estimate gridded temperatures. (Adapted and updated from Zhang et al. 2000) 
Winter

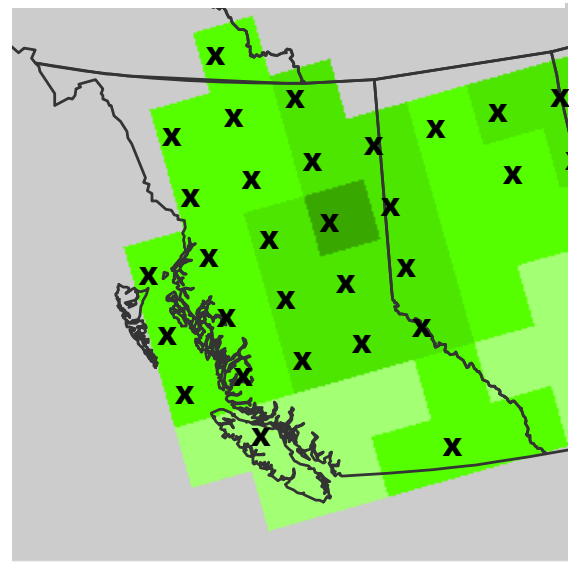

Summer

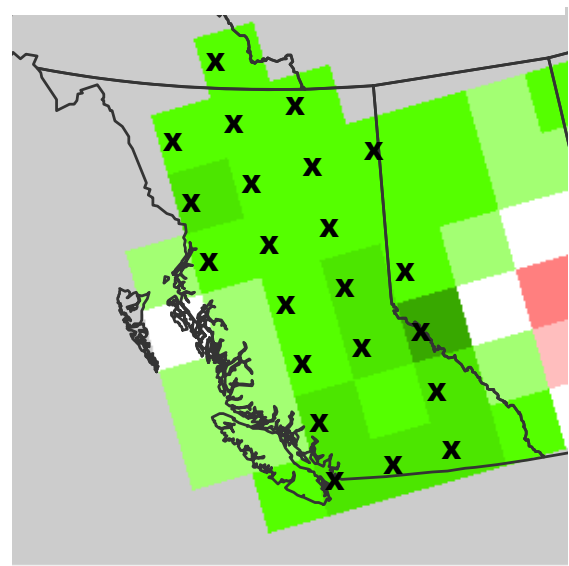

Annual

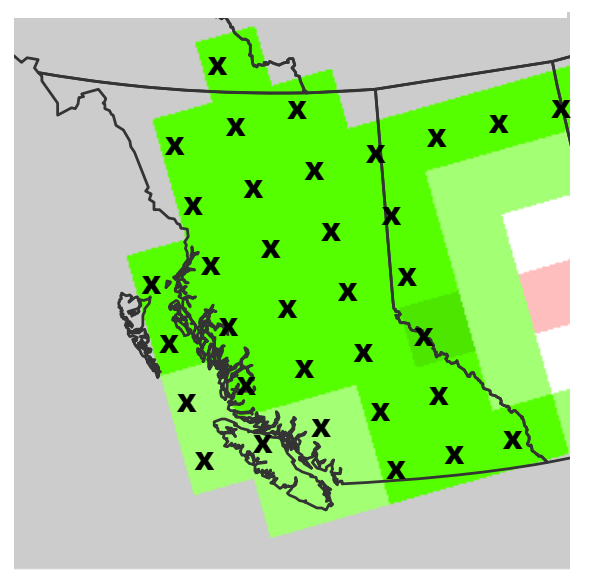

Spring

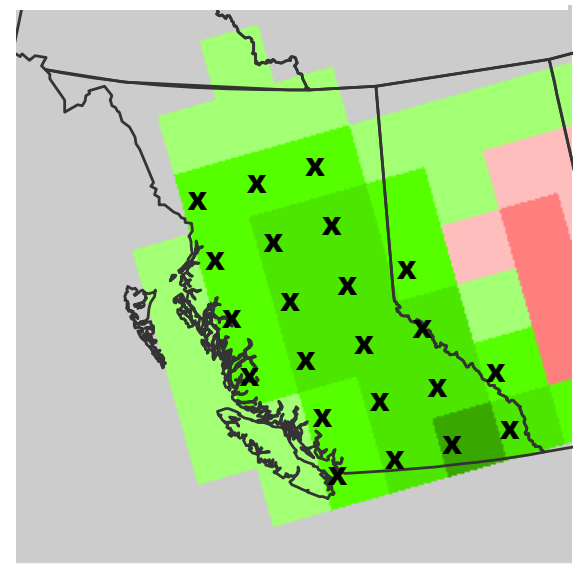

Fall

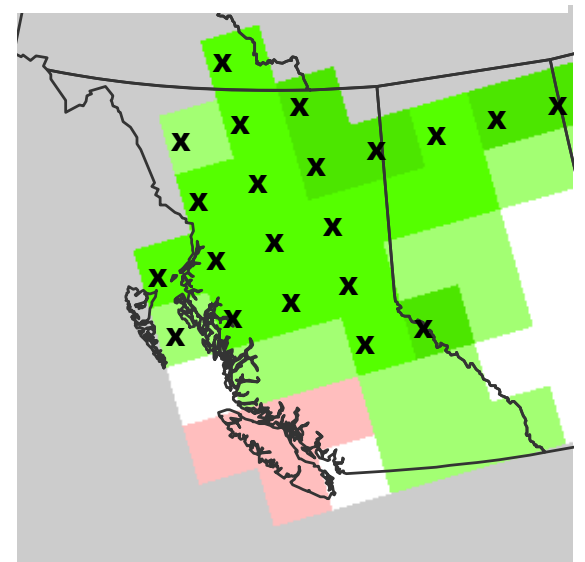

FIGURE 3.19 Trends in precipitation totals for the period 1900-2003 for western Canada. Units are percentage change per year over the 104-year period. Grid cells with crosses indicate trends that are significant at a 5\% significance level. Grey cells indicate areas with insufficient data to estimate gridded temperatures. (Adapted and updated from Zhang et al. 2000) 

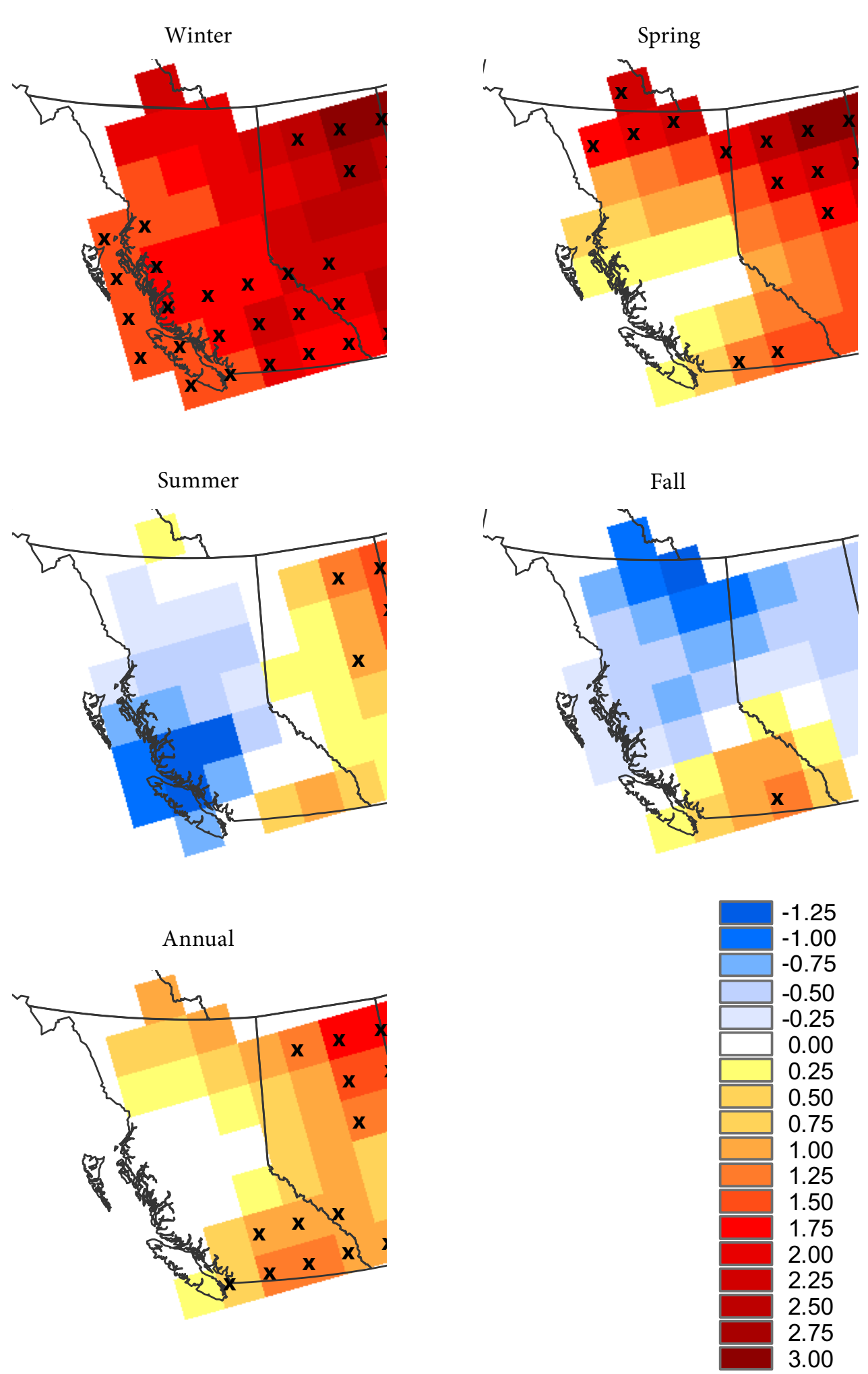

FIGURE 3.20 Trends in daily maximum air temperature for the period 1900-2003 for western Canada. Units are degrees Celsius for the 104-year period. Grid cells with crosses indicate trends that are significant at a 5\% significance level. Grey cells indicate areas with insufficient data to estimate gridded temperatures. (Adapted and updated from Zhang et al. 2000) 
a) Cold days

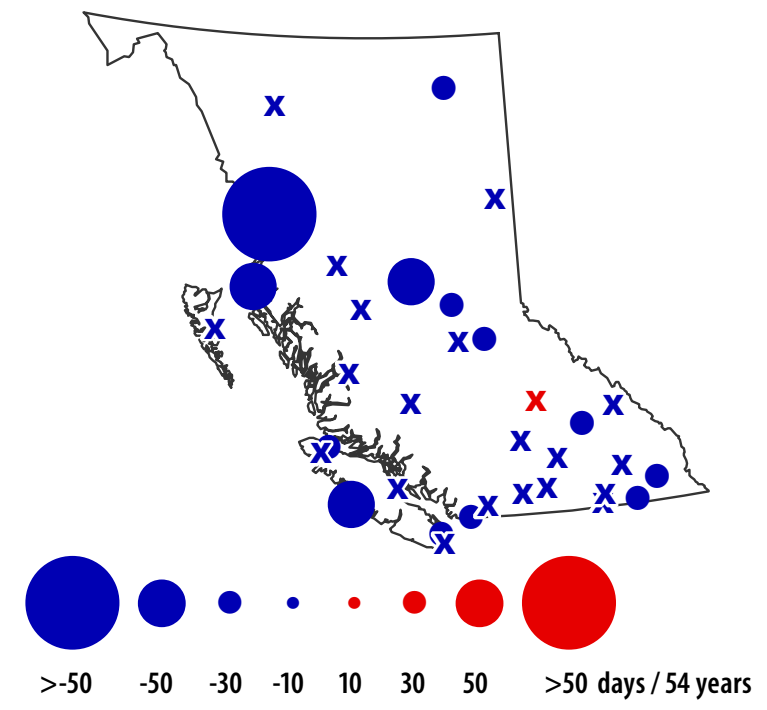

c) Cold nights

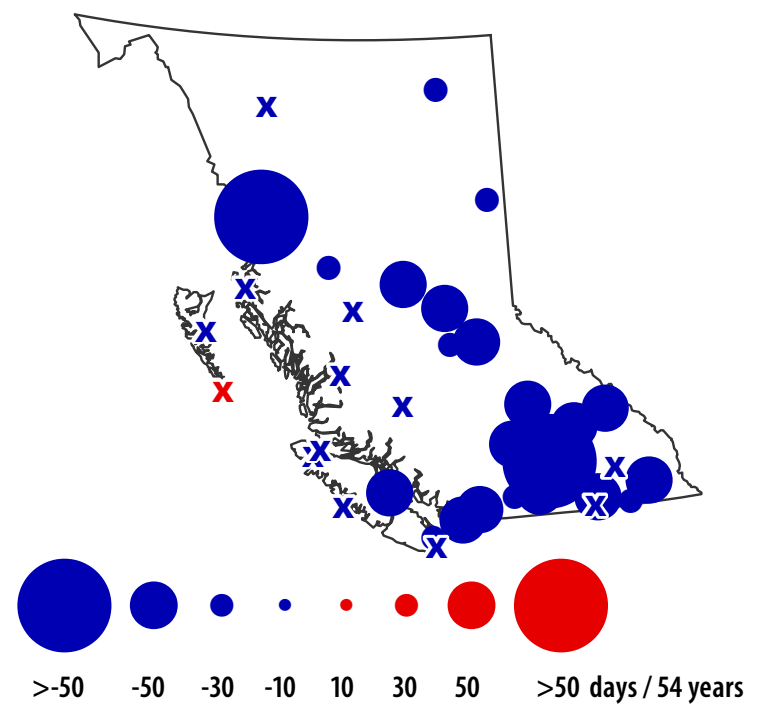

b) Warm days

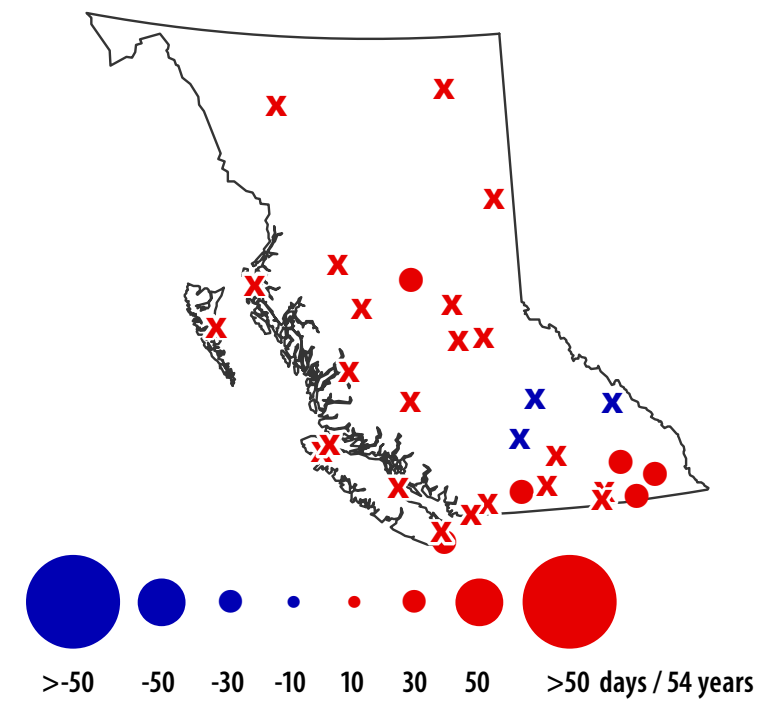

d) Warm nights

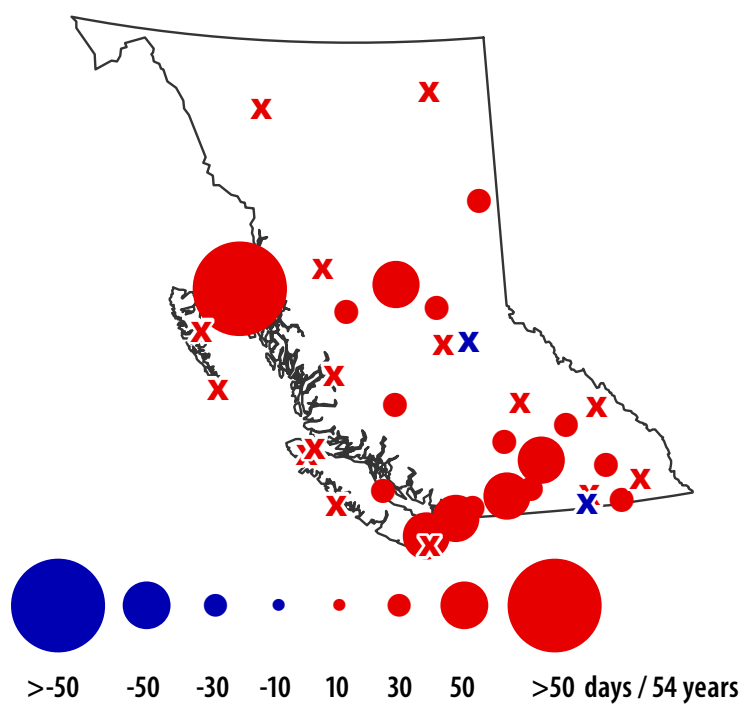

FIGURE 3.21 Trends in four temperature metrics at climate stations within British Columbia for the period 1950-2003. Metrics are the frequencies per year of cold/warm days/nights, indicated by temperatures below/above defined thresholds. Dots indicate trends that are significant at a 5\% significance level. Dot area is scaled to indicate the magnitude of the trend. (Adapted and updated from Vincent and Mekis 2006) 
a) Annual snowfall precipitation

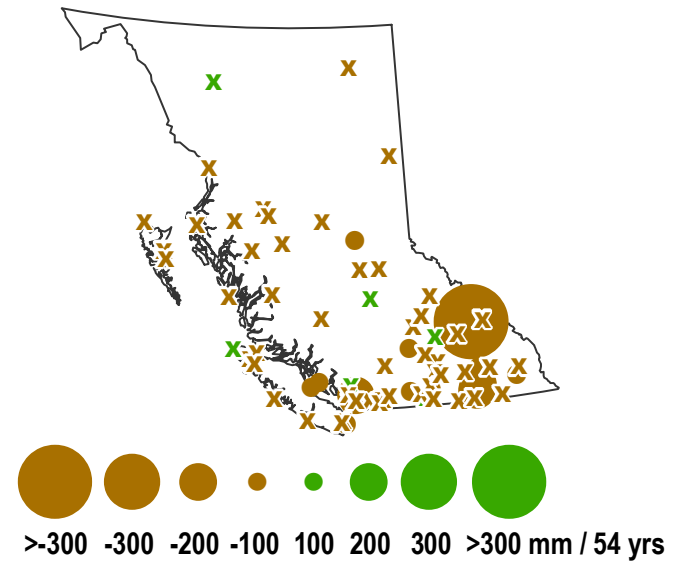

c) Days with precipitation

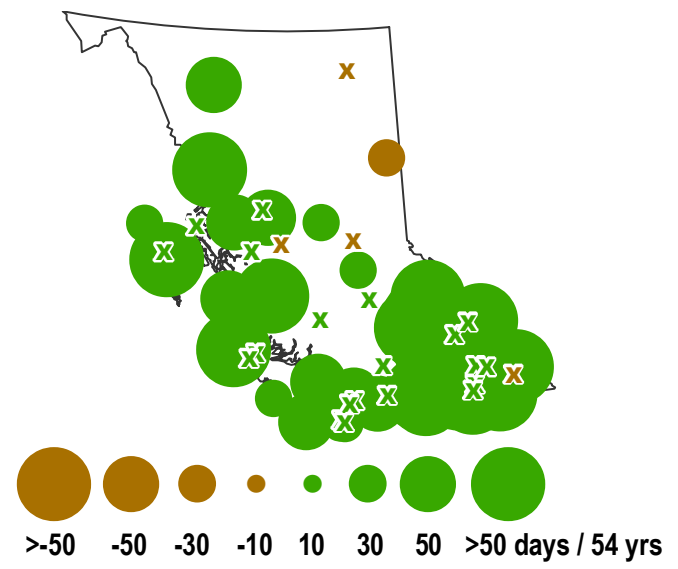

e) Simple day intensity index of $\mathrm{P}$

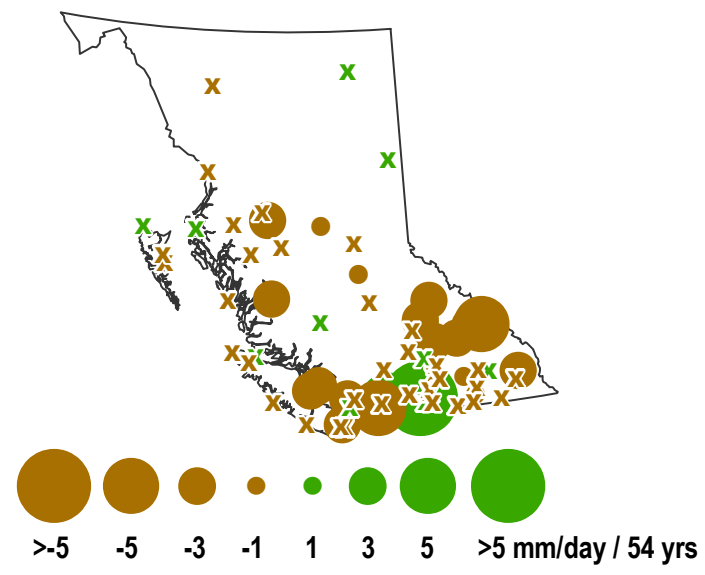

b) Snow to total precipitation ratio

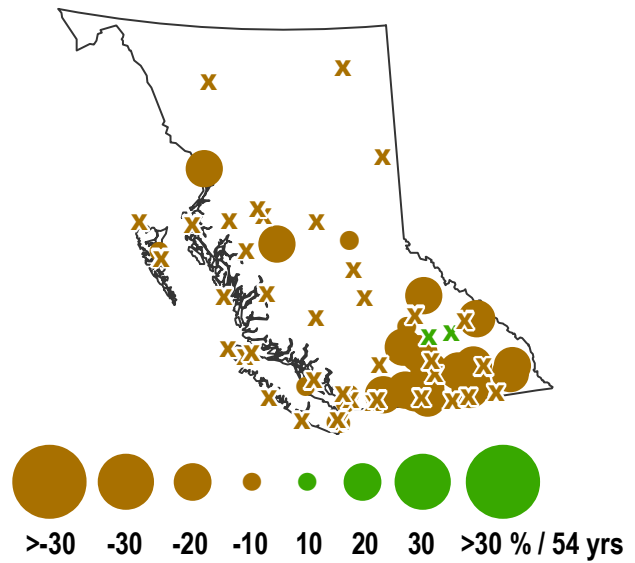

d) Days with rain

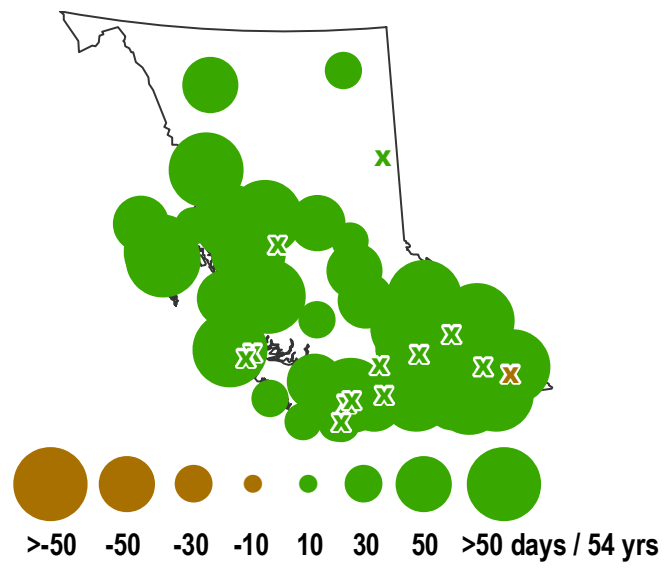

f) Simple day intensity index of R

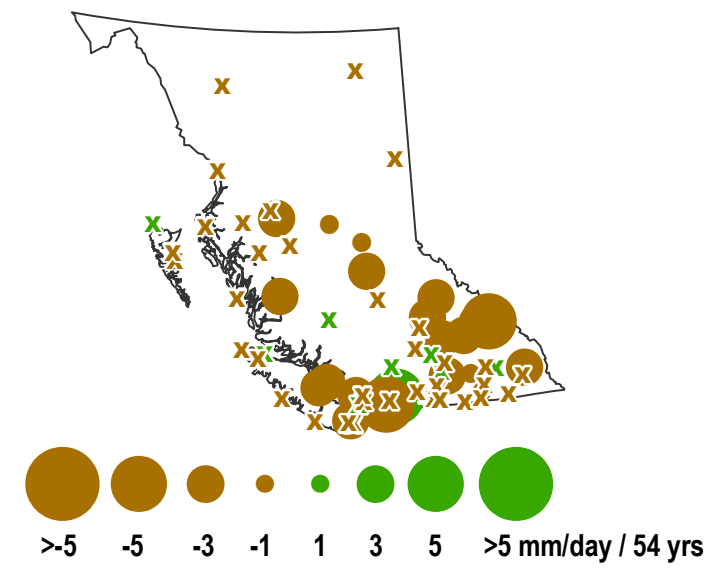

FIGURE 3.22 Trends in six precipitation metrics at climate stations within British Columbia for the period 1950-2003. Brown and green dots indicate trends significant at the 5\% level. Dot area is scaled to indicate the magnitude of the trend. Crosses denote non-significant trends. (Adapted and updated from Vincent and Mekis 2006) 
The Intergovernmental Panel on Climate Change uses multiple scenarios to generate possible future climatic conditions. Each scenario is based on a "story line" about developments in technology, economic growth, and international cooperation (Intergovernmental Panel on Climate Change 2007). For each scenario, emissions of greenhouse gases are estimated and used as input to global climate models (GCMs). This approach explicitly acknowledges the inherent uncertainties in predicting future socio-economic conditions. The GCMs that generate projections of future climatic conditions are also a source of uncertainty because of differences in how certain atmospheric and oceanic processes are modelled. Consequently, a single future climate projection is not considered more likely than another, but the models allow bounds to be placed on the range of possible outcomes. For more details on climate variability and trends see Chapter 19 ("Climate Change Effects on Watershed Processes in British Columbia").

Figure 3.23 shows a range of future climate projections for three emission scenarios and a number of GCMs. The A2 scenario assumes that emissions will continue to increase without any significant efforts to reduce them. The $\mathrm{B} 1$ scenario assumes that the rate of emission increases will slow down soon and begin to decrease by the middle of the century. Scenario $\mathrm{A} 1 \mathrm{~B}$ is intermediate between the $\mathrm{A} 2$ and $\mathrm{B} 1$ scenarios (Intergovernmental Panel on Climate Change 2007). The gold line shows that even if all emissions ceased immediately, an additional $0.5^{\circ} \mathrm{C}$ warming would occur because of the effects of a lag in heat distribution in the oceans. Changes in precipitation will accompany changes in temperature.

Model projections indicate that British Columbia will have greater warming and changes in precipitation than the global average (Intergovernmental
Panel on Climate Change 2007). A range of future climates is possible, depending on the future emissions and the GCM (Table 3.6). The main feature illustrated in Table 3.6 is that all models and emissions scenarios produce an increase in temperature that grows with time. Not shown in Table 3.6 is that warming tends to be greater for minimum temperatures than for maximum temperatures. Projected changes in precipitation are quite variable. Generally, southern and central British Columbia are expected to get drier in the summer, and northern British Columbia is more likely to be wetter. Winters will, in general, become wetter across British Columbia, with a greater increase in the north. Figures 3.243.28 illustrate what such changes in climate would mean for British Columbia using the A2 emission scenario (minimal control of emissions) as simulated by the Canadian Global Climate Model version 2. Table 3.7 presents historic climatic conditions for selected locations in British Columbia, along with projections based on the A2 scenario. Other possible future climates are equally likely.

The projections in Tables 3.6 and 3.7, and Figures 3.23-3.28, are based on multi-year averages. However, as noted previously, extreme events are often more important than long-term climatic means. In the simulations of future climate, changes in warm extremes follow changes in the mean summertime temperature. Cold extremes warm faster, particularly in areas that experience a retreat of snow with warming. There is also an increased intensity of precipitation regimes and a reduction in return periods of current extreme events (Kharin et al. 2007). Note that, while only projections for temperature and precipitation are discussed here, GCMs also generate projections for humidity, wind speed, and solar radiation, which users can access if needed. 


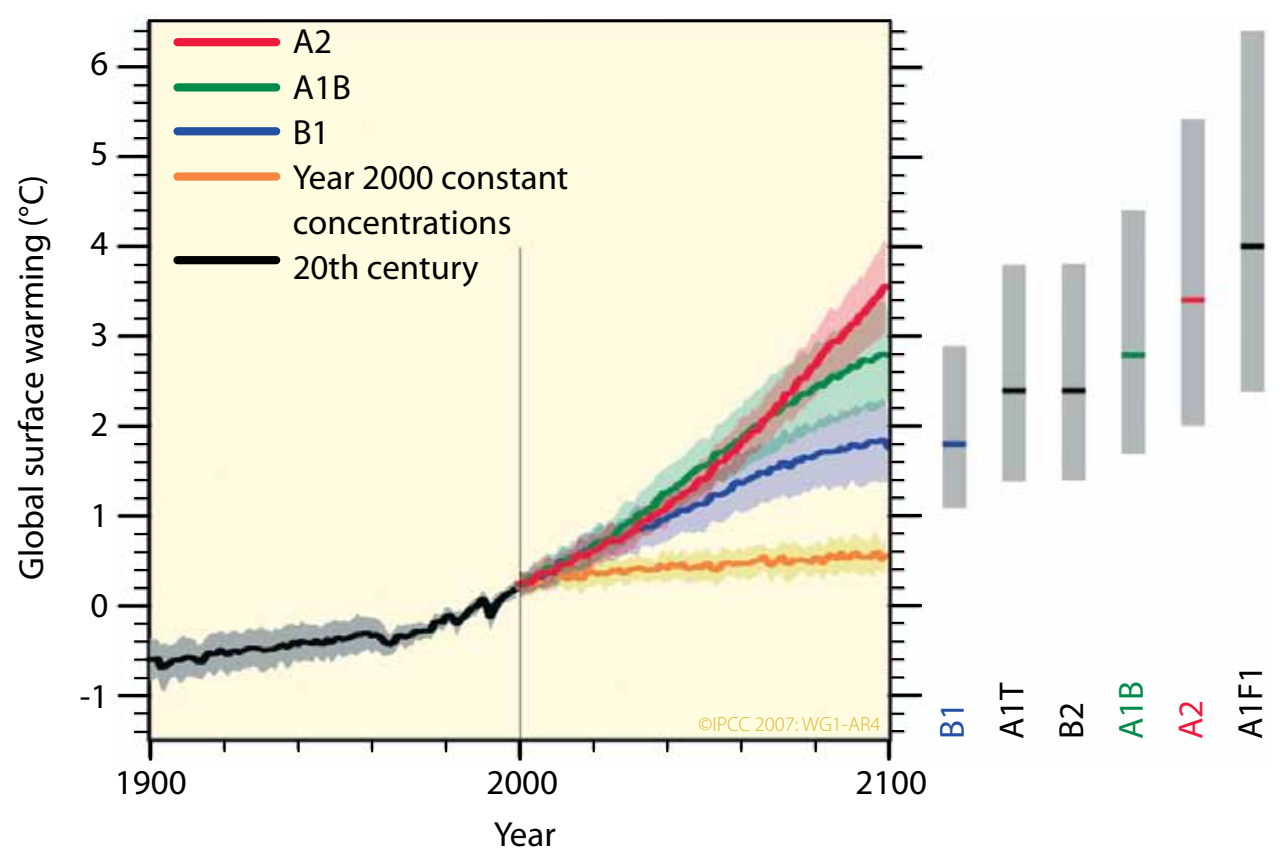

FIGURE 3.23 A range of future climate projections for three emission scenarios and a number of global climate models. Solid lines are multi-model global averages of surface warming (relative to 1980-1999) for the scenarios A2, A1B, and B1, shown as continuations of the 20th-century simulations. Shading denotes the \pm 1 standard deviation range of individual model annual averages. The orange line is for an experiment in which concentrations were held constant at year 2000 values. The grey bars at right indicate the best estimate (solid line within each bar) and the likely range assessed for the six Special Report on Emission Scenarios marker emissions scenarios. The assessment of the best estimate and likely ranges in the grey bars includes the coupled atmosphere ocean general circulation models in the left part of the figure, as well as results from a hierarchy of independent models and observational constraints. (Intergovernmental Panel on Climate Change 2007)

TABLE 3.6 Climate change scenarios (seven models and eight emission scenarios). Data are the changes from 1961 to 1990 climate as a change in mean temperature or a percentage change in total precipitation (PPT). Values are based on data from the Canadian Climate Change Scenarios Network (www.cccsn.ca) and Pacific Climate Impacts Consortium (www.pacificclimate.org).

\begin{tabular}{|c|c|c|c|c|c|c|}
\hline & \multicolumn{2}{|c|}{2020} & \multicolumn{2}{|c|}{2050} & \multicolumn{2}{|c|}{2080} \\
\hline & $\begin{array}{c}\text { Temperature } \\
\left({ }^{\circ} \mathbf{C}\right)\end{array}$ & $\begin{array}{c}\mathbf{P P T} \\
(\%)\end{array}$ & $\begin{array}{c}\text { Temperature } \\
\left({ }^{\circ} \mathrm{C}\right)\end{array}$ & $\begin{array}{c}\text { PPT } \\
(\%)\end{array}$ & $\begin{array}{c}\text { Temperature } \\
\left({ }^{\circ} \mathrm{C}\right)\end{array}$ & $\begin{array}{c}\text { PPT } \\
(\%)\end{array}$ \\
\hline \multicolumn{7}{|c|}{ Southern British Columbia } \\
\hline Winter & 0 to 2 & -5 to +15 & 1.5 to 3.5 & 0 to +20 & 2 to 7 & 0 to 25 \\
\hline Summer & 0.5 to 2 & -30 to +5 & 1.5 to 4 & -35 to 0 & 2.5 to 7.5 & -50 to 0 \\
\hline \multicolumn{7}{|c|}{ Central British Columbia } \\
\hline Winter & 0 to 2 & -5 to +15 & 1.5 to 4 & 0 to +30 & 2.5 to 6 & +5 to +40 \\
\hline Summer & 0.5 to 1.5 & -10 to +5 & 1.8 to 3.5 & -20 to 0 & 2.5 to 6.5 & -20 to +5 \\
\hline \multicolumn{7}{|c|}{ Northern British Columbia } \\
\hline Winter & 0 to 2.5 & 0 to 20 & 1.5 to 5.5 & 0 to +25 & 2.5 to 9 & 0 to +45 \\
\hline Summer & 0.5 to 1.5 & -10 to +10 & 1.5 to 3.5 & -10 to +15 & 2 to 6 & -15 to +25 \\
\hline
\end{tabular}


TABLE 3.7 Climate change scenarios for five locations in British Columbia based on the Canadian global climate model simulations for the A2 emission scenario (CCCM2 a2x; obtained using the ClimateBC software [Wang et al. 2006; Spittlehouse 2006, 2008]).

\begin{tabular}{|c|c|c|c|c|c|c|c|}
\hline & $\begin{array}{l}\text { MAT }^{\mathbf{a}} \\
\left({ }^{\circ} \mathrm{C}\right)\end{array}$ & $\begin{array}{l}\text { MWMT } \\
\left({ }^{\circ} \mathrm{C}\right)\end{array}$ & $\begin{array}{l}\text { MCMT } \\
\left({ }^{\circ} \mathrm{C}\right)\end{array}$ & $\begin{array}{l}\text { MAP } \\
(\mathbf{m m})\end{array}$ & $\begin{array}{l}\text { MSP } \\
(\mathbf{m m})\end{array}$ & $\begin{array}{l}\text { FFP } \\
\text { (days) }\end{array}$ & SH:M \\
\hline \multicolumn{8}{|l|}{ Castlegar } \\
\hline 1961-1990 & 8.3 & 19.9 & -3.2 & 732 & 284 & 153 & 70 \\
\hline $2020 \mathrm{~s}$ & 9.5 & 21.1 & -1.8 & 750 & 279 & 169 & 76 \\
\hline $2050 s$ & 10.6 & 22.2 & -0.4 & 744 & 263 & 181 & 84 \\
\hline $2080 \mathrm{~s}$ & 12.2 & 23.6 & 0.6 & 767 & 255 & 210 & 93 \\
\hline \multicolumn{8}{|l|}{ Fort Nelson } \\
\hline 1961-1990 & -1.1 & 16.7 & -22.0 & 449 & 303 & 106 & 55 \\
\hline $2020 s$ & 0.1 & 18.2 & -20.3 & 466 & 312 & 118 & 58 \\
\hline $2050 s$ & 1.5 & 19.3 & -17.9 & 477 & 313 & 130 & 62 \\
\hline $2080 \mathrm{~s}$ & 3.3 & 20.8 & -14.5 & 499 & 329 & 145 & 63 \\
\hline \multicolumn{8}{|l|}{ Kelowna } \\
\hline 1961-1990 & 7.4 & 18.8 & -4.5 & 366 & 171 & 125 & 110 \\
\hline $2020 s$ & 8.6 & 19.9 & -3.4 & 374 & 170 & 139 & 117 \\
\hline $2050 \mathrm{~s}$ & 9.7 & 21.0 & -2.1 & 369 & 161 & 152 & 130 \\
\hline $2080 s$ & 11.2 & 22.4 & -1.0 & 375 & 158 & 176 & 142 \\
\hline \multicolumn{8}{|c|}{ Prince George } \\
\hline 1961-1990 & 3.7 & 15.3 & -9.9 & 615 & 287 & 93 & 53 \\
\hline $2020 s$ & 4.9 & 16.5 & -8.2 & 615 & 280 & 110 & 59 \\
\hline $2050 \mathrm{~s}$ & 6.1 & 17.5 & -6.4 & 630 & 285 & 127 & 61 \\
\hline $2080 \mathrm{~s}$ & 7.7 & 18.8 & -4.9 & 635 & 275 & 149 & 68 \\
\hline \multicolumn{8}{|l|}{ Port Hardy } \\
\hline 1961-1990 & 8.1 & 13.9 & 3.0 & 1871 & 410 & 183 & 33 \\
\hline $2020 s$ & 9.1 & 14.8 & 3.9 & 1885 & 394 & 208 & 38 \\
\hline $2050 \mathrm{~s}$ & 10.1 & 15.9 & 4.9 & 1935 & 387 & 259 & 41 \\
\hline $2080 \mathrm{~s}$ & 11.4 & 17.2 & 6.1 & 2035 & 373 & 324 & 46 \\
\hline
\end{tabular}

a $\quad$ MAT $=$ mean annual temperature; $\mathrm{MWMT}=$ mean warmest month temperature (July); MCMT $=$ mean coldest month temperature (January); MAP = mean annual precipitation; MSP = mean summer precipitation (May to September); FFP = frost-free period; SH:M = summer heat:moisture index. 


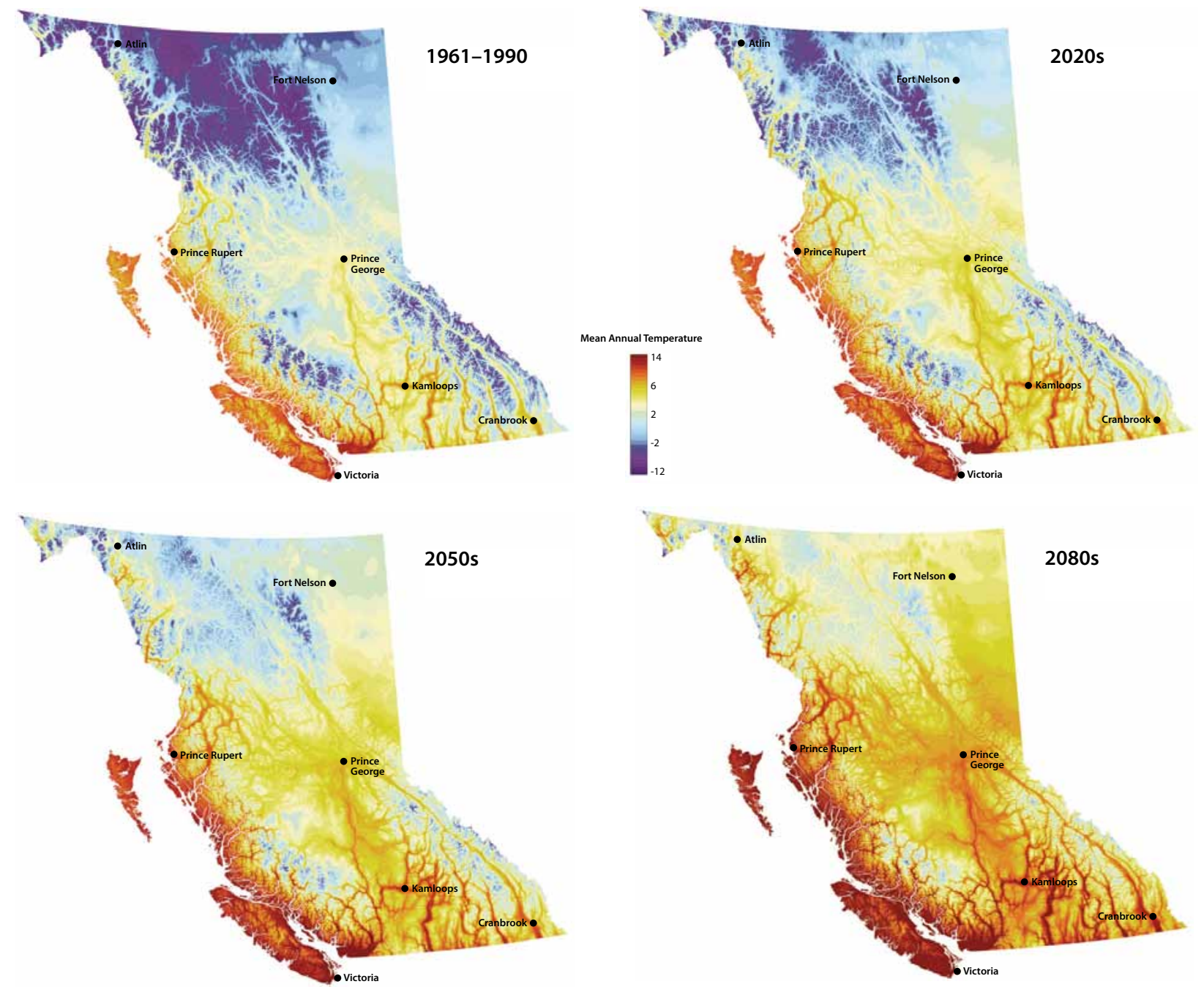

FIGURE 3.24 Mean annual temperature for British Columbia for current climate (1961-1990 average) and that predicted for British Columbia in 2020s, 2050s, and 2080s for the A2 scenario from Canadian Global Climate Model version 2.

Downscaling was done with ClimateBC (Spittlehouse 2006, 2008; Wang et al. 2006). 


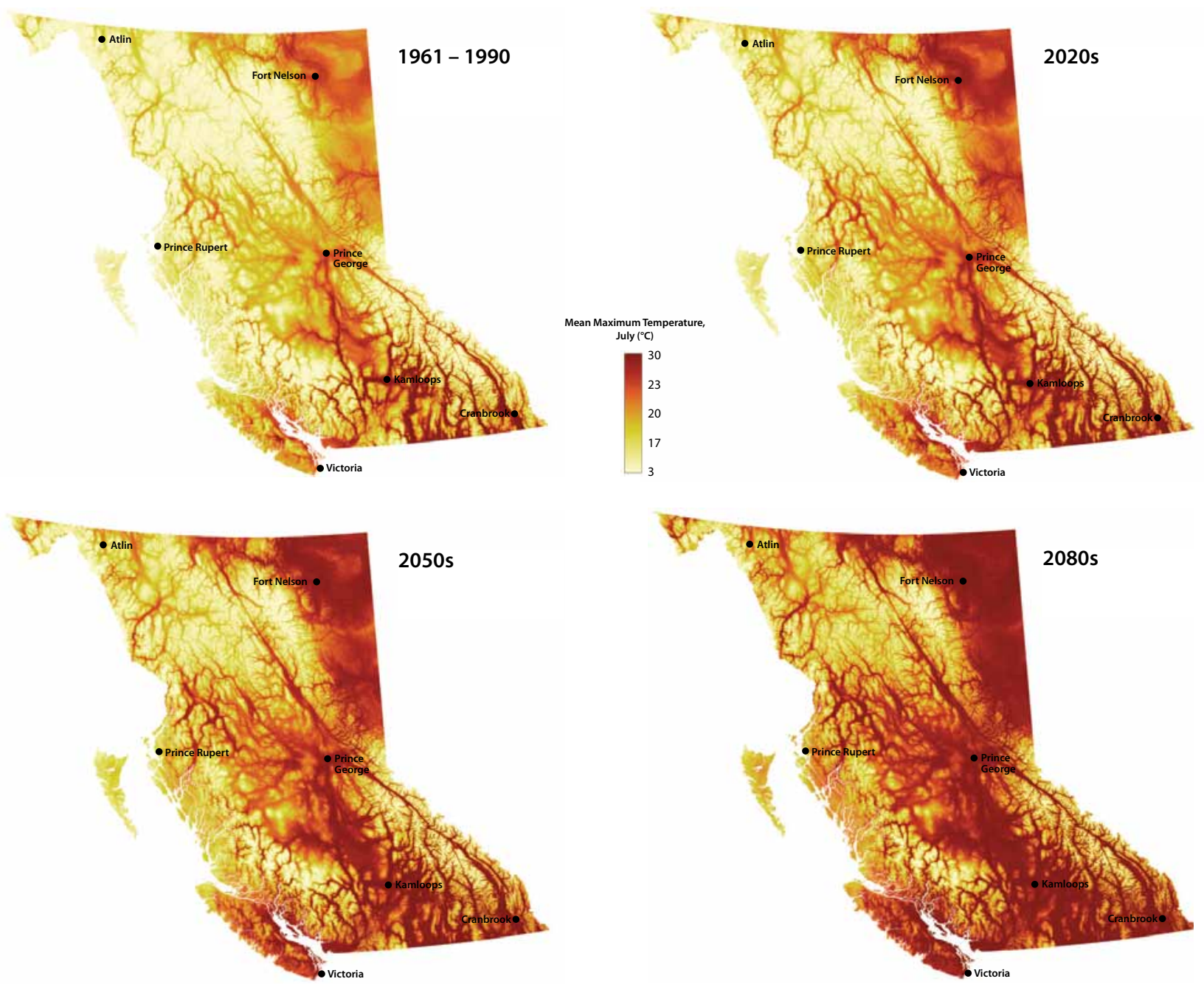

FIGURE 3.25 Mean maximum July temperature for British Columbia for current climate (1961-1990 average) and that predicted for British Columbia in 2020s, 2050s, and 2080s for the A2 scenario from Canadian Global Climate Model version 2. Downscaling was done with ClimateBC (Spittlehouse 2006, 2008; Wang et al. 2006). 


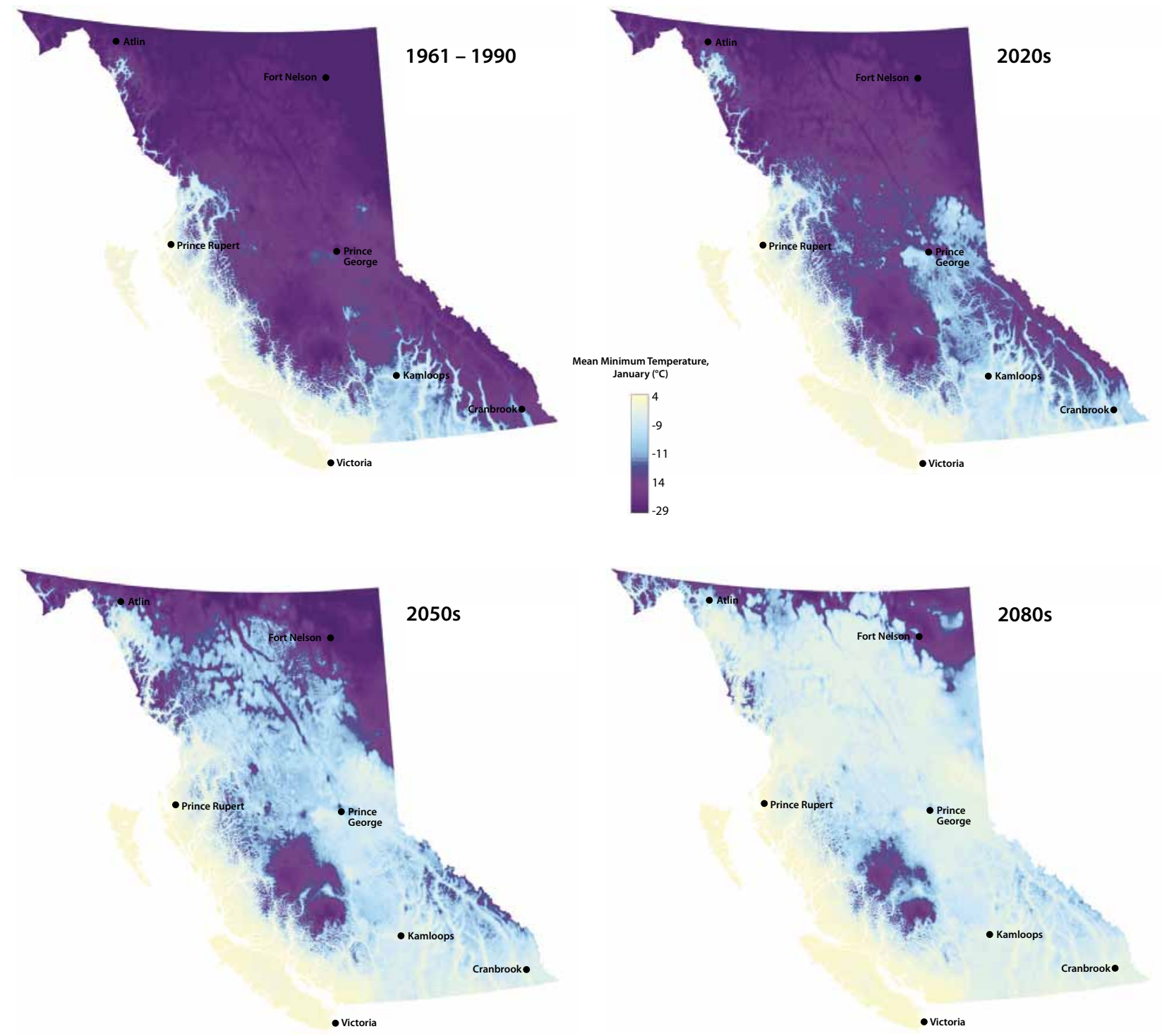

FIGURE 3.26 Mean minimum January temperature for British Columbia for current climate (1961-1990 average) and that predicted for British Columbia in 2020s, 2050s, and 2080s for the A2 scenario from Canadian Global Climate Model version 2. Downscaling was done with ClimateBC (Spittlehouse 2006, 2008; Wang et al. 2006). 

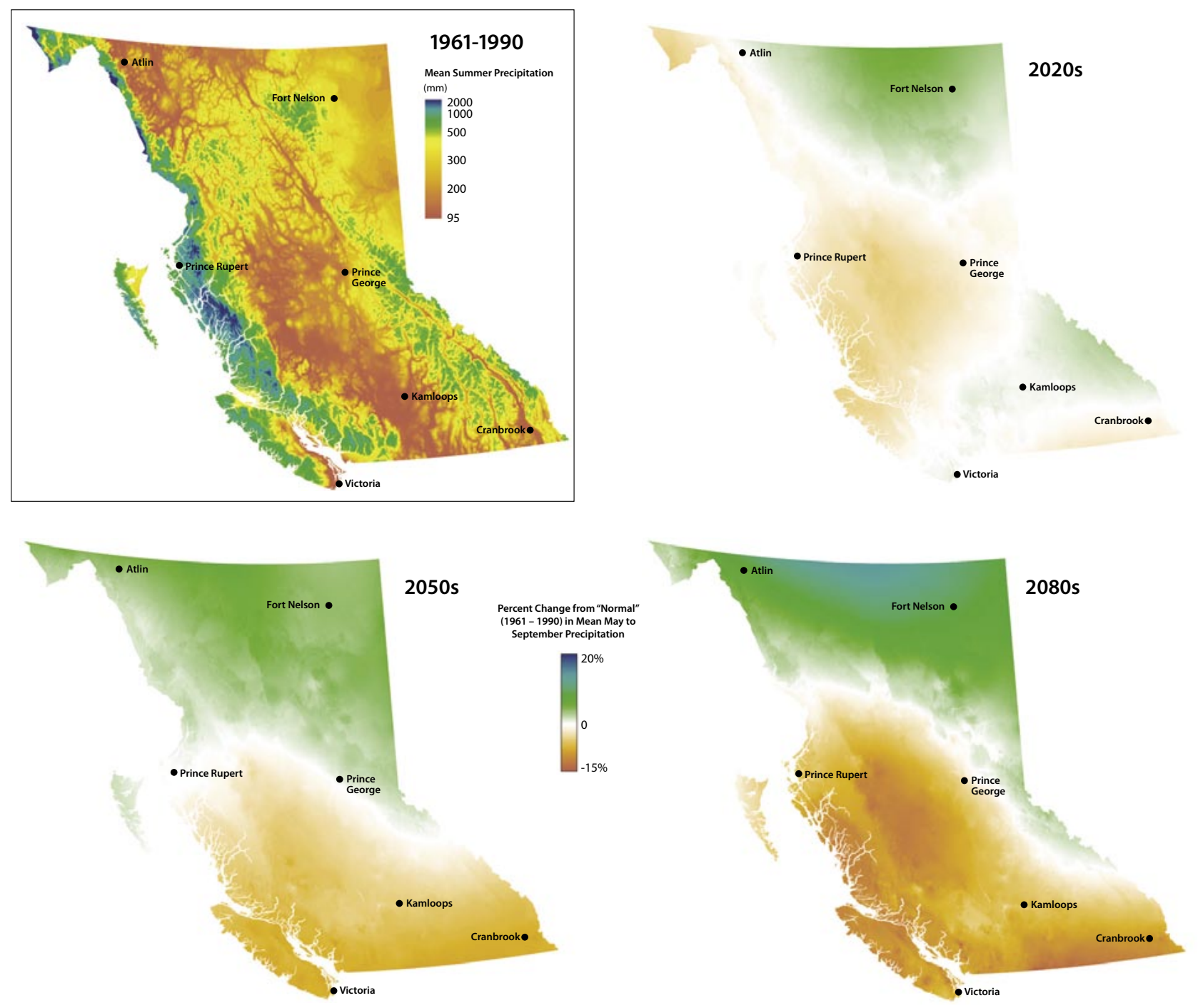

FIGURE 3.27 Mean May to September precipitation for British Columbia for current climate (1961-1990 average) and the percentage change predicted for British Columbia in 2020s, 2050s, and 2080s for the A2 scenario from Canadian Global Climate Model version 2. Downscaling was done with ClimateBC (Spittlehouse 2006, 2008; Wang et al. 2006). 

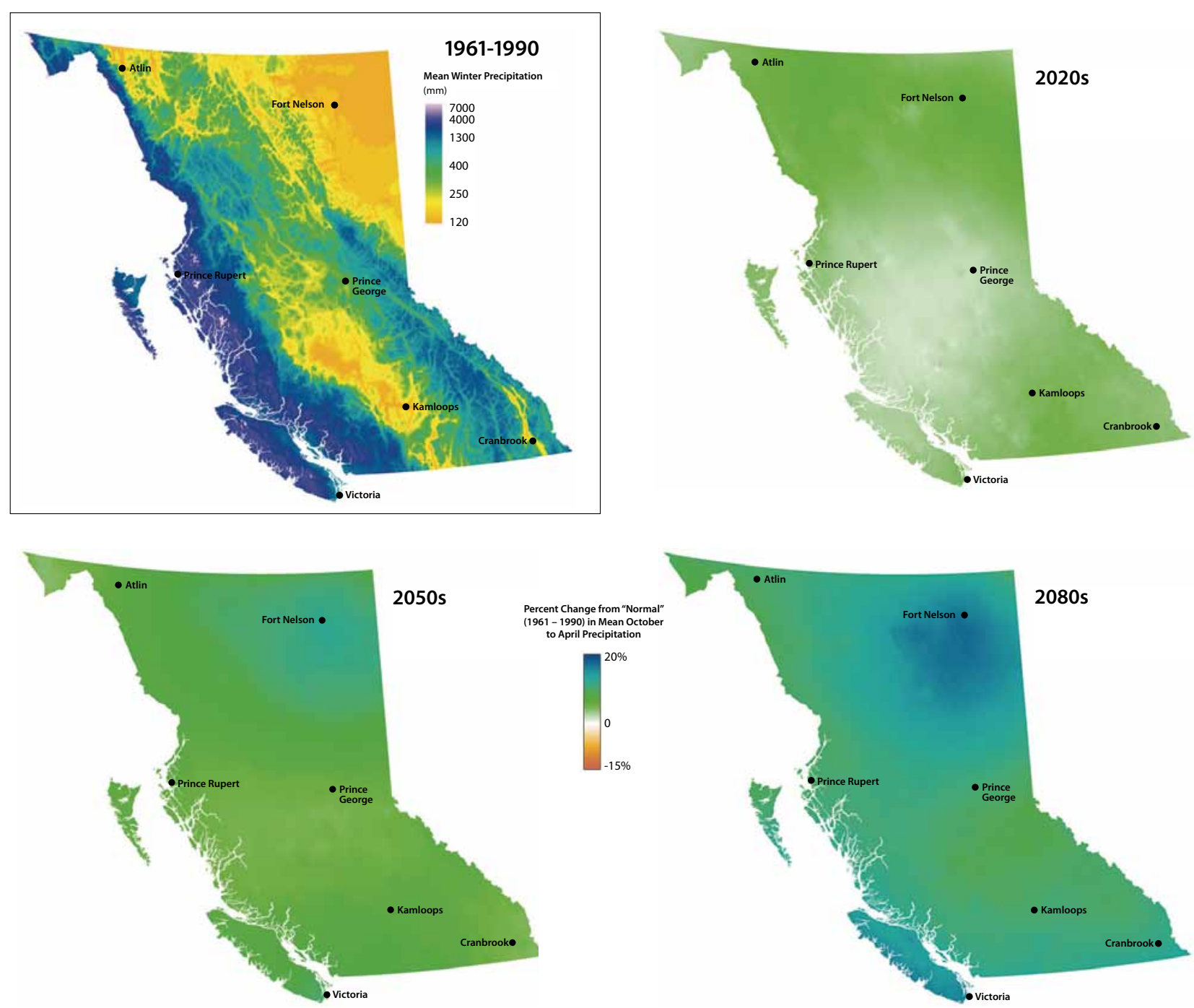

FIGURE 3.28 Mean October to April precipitation for British Columbia for current climate (1961-1990 average) and the percentage change predicted for British Columbia in 2020s, 2050s, and 2080s for the A2 scenario from Canadian Global Climate Model version 2. Downscaling was done with ClimateBC (Spittlehouse 2006, 2008; Wang et al. 2006). 
This chapter has drawn upon research conducted with funding assistance from the Government of Canada's Climate Change Impacts and Adaptations Research Program via grants A676 and A875. Adrian Walton (B.C. Ministry of Forests and Range, Research Branch) produced the climate maps of current and future climates for British Columbia. Carol
Cheuk (Environment Canada) produced the images of climate trends. Dave Hutchinson and Anne McCarthy (Environment Canada) assisted with access to weather data. The authors also thank Eva Mekis, Lucie Vincent, and Xuebin Xhang for access to their software that allowed us to create updated versions of Figures 3.18-3.22.

\section{REFERENCES}

Allen, R.G., L.S. Pereira, D. Raes, and M. Smith (editors). 1998. Crop evapotranspiration: guidelines for computing crop water requirements. U.N. Food Agric. Org., Rome, Italy. FAO Irrigation and Drainage Pap. FAO56. www.fao.org/ docrep/Xo49oE/Xo49oEoo.htm (Accessed March 2010).

B.C. Ministry of Forests and Range. 2008. Biogeoclimatic zones of British Columbia [Map]. B.C. Min. For. Range, Res. Br., Victoria, B.C. www. for.gov.bc.ca/hre/becweb/resources/maps/ map_download.html (Accessed March 2010).

B.C. Ministry of Water, Land and Air Protection. 2002. Indicators of climate change for British Columbia, 2002. Victoria, B.C. www.env. gov.bc.ca/cas/pdfs/indcc.pdf (Accessed March 2010).

Bonsal, B.R., A. Shabbar, and K. Higuchi. 2001a. Impact of low frequency variability modes on Canadian winter temperature. Int. J. Climatol. 21:95-108.

Bonsal, B.R., X. Zhang, L.A. Vincent, and W.D. Hogg. 2001b. Characteristics of daily and extreme temperatures over Canada. J. Climate 14:1959-1976.

Chilton, R.H. 1981. A summary of climate regimes of British Columbia. B.C. Min. Environ., Victoria, B.C.

Church, M. and M.J. Miles. 1987. Meteorological antecedents to debris flow in southwestern British Columbia: some case studies. In: Proc. debris flows/avalanches: process, recognition and mitigation. N.V. Reno, J.E. Costa, and G.F.
Wieczorek (editors). Rev. Eng. Geol. 7, Geol. Soc. Am., Boulder, Colo., pp. 63-79.

Egginton, V.N. 2005. Historical climate variability from the instrumental record in Northern British Columbia and its influence on slope stability. MSc thesis. Simon Fraser Univ., Burnaby, B.C.

Fleming, S.W. 2006. Average historical impacts of Pacific ocean-atmosphere circulation modes on British Columbia and Yukon annual temperature and precipitation cycles. Prepared for Environ. Can., Meteorol. Serv. Can. Aquatic Informatics, Vancouver, B.C. www.aquatic informatics.com/UserFiles/File/Average\%2ohis torical\%20impacts\%202006\%2oreport.pdf (Accessed March 2010).

Fleming, S.W., P.H. Whitfield, R.D. Moore, and E.J. Quilty. 2007. Regime-dependent streamflow sensitivities to Pacific climate modes across the Georgia-Puget transboundary ecoregion. Hydrol. Process. 21:3264-3287.

Hare, S.R. and N.J. Mantua. 200o. Empirical evidence for North Pacific regime shifts in 1977 and 1989. Progr. Oceanogr. 47(2-4):103-146.

Hélie, J.F., D.L. Peters, K.R. Tattrie, and J.J. Gibson. 2005. Review and synthesis of potential hydrologic impacts of mountain pine beetle and related harvesting activities in British Columbia. Nat. Resour. Can., Can. For. Serv., Pac. For. Cent., Victoria, B.C. Mountain Pine Beetle Initiative Work. Pap. 2005-23.

Hsieh, W.W. and B. Tang. 2001. Interannual variability of accumulated snow in the Columbia 
basin, British Columbia. Water Resour. Res. 37:1753-1760.

Intergovernmental Panel on Climate Change. 2007. Summary for policymakers. In: Climate change 2007: The physical science basis. Contribution of Working Group I to the Fourth Assessment Report of the Intergovernmental Panel on Climate Change. S. Solomon, D. Qin, M. Manning, Z. Chen, M. Marquis, K.B. Averyt, M. Tignor, and H.L. Miller (editors). Cambridge University Press, Cambridge, U.K. and New York, N.Y. www.ipcc.ch/publications and_data/ar4/wg1/en/spm.html (Accessed March 2010).

Jakob, M., K. Holm, O. Lange, and J. Schwab. 2006. Hydrometeorological thresholds for landslide initiation and forest operation shutdowns on the north coast of British Columbia. Landslides 3:228-238.

Jakob, M. and H. Weatherly. 2003. A hydroclimatic threshold for landslide initiation on the North Shore Mountains of Vancouver, British Columbia. Geomorphology 54:137-156.

Kharin, V.V., F.W. Zwiers, X. Zhang, and G.C. Hagerl. 2007. Changes in temperature and precipitation extremes in the IPCC ensemble of global coupled model simulations. J. Climate 20:1419-1444.

Mantua, N.J., S.R. Hare, Y. Zhang, J.M. Wallace, and R.C. Francis. 1997. A Pacific interdecadal climate oscillation with impacts on salmon production. Bull. Am. Meteorol. Soc. 78:10691079.

Mather, J.R. and R.A. Ambroziak. 1986. A search for understanding potential evapotranspiration. Geogr. Rev. 76:355-370.

Moore, R.D. 1991. Hydrology and water supply in the Fraser River basin. In: Water in sustainable development: exploring our common future in the Fraser River basin. A.H.J. Dorcey and J.R. Griggs (editors). Univ. British Columbia, Westwater Res. Cent., Vancouver, B.C., pp. 21-40.

. 1996. Snowpack and runoff responses to climatic variations, southern Coast Mountains, British Columbia, Canada. N.W. Sci. 70:321-333.
Moore, R.D. and M.N. Demuth. 2001. Mass balance and streamflow variability at Place Glacier, Canada, in relation to recent climate fluctuations. Hydrol. Process. 15:3473-3486.

Moore, R.D. and I.G. McKendry. 1996. Spring snowpack anomaly patterns and winter climatic variability, British Columbia, Canada. Water Resour. Res. 32:623-632.

Moore, R.D., D.L. Spittlehouse, and A. Story. 2005. Riparian microclimate and stream temperature response to forest harvesting: a review. J. Am. Water Resour. Assoc. 41:813-834.

Phillips, D. 1980. The climates of Canada. Supply Serv. Can., Ottawa, Ont.

Rosenberg, S.M., I.R. Walker, R.W. Mathewes, and D.J. Hallett. 2004. Midge-inferred Holocene climate history of two subalpine lakes in southern British Columbia. Holocene 14:258-271.

Shabbar, A., B.R. Bonsal, and M. Khandekar. 1997. Canadian precipitation patterns associated with the southern oscillation. J. Climate 10:3016-3027.

Shabbar, A. and M. Khandekar. 1996. The impact of El Niño-southern oscillation on the temperature field over Canada. Atmos. Ocean 34:401-416.

Spittlehouse, D.L. 2003. Water availability, climate change and the growth of Douglas-fir in the Georgia Basin. Can. Water Resour. J. 28(4):673-688.

2004. The climate and long-term water balance of Fluxnet Canada's coastal Douglas-fir forest. In: Proc. 26th Conf. Agric. For. Meteorol. Aug. 23-26, 2004, Vancouver, B.C., Am. Meteorol. Soc., Boston, Mass.

2006. ClimateBC: your access to interpolated climate data for BC. Streamline Watershed Manag. Bull. 9(2):16-21. www.forrex.org/ publications/streamline/ISS31/streamline_ vol9_no2_art4.pdf (Accessed March 2010).

.2008. Climate change, impacts, and adaptation scenarios: Climate change and forests and range management in British Columbia. B.C. Min. For. Range, Res. Br., Victoria, B.C. Tech. Rep. No. 045, www.for.gov.bc.ca/hfd/pubs/ docs/tr/tro45.pdf (Accessed May 2010). 
Stahl, K. and R.D. Moore. 2006. Influence of watershed glacier coverage on summer streamflow in British Columbia, Canada. Water Resour. Res. 42, Wo6201. DOI:10.1029/2006WRo05022.

Stahl, K., R.D. Moore, J.A. Floyer, M.G. Asplin, and I.G. McKendry. 2006c. Comparison of approaches for spatial interpolation of daily air temperature in a large region with complex topography and highly variable station density. Agric. For. Meteorol. 139:224-236. DOI:10.10.1016/j.agrformet.2006.07.004.

Stahl, K., R.D. Moore, and I.G. McKendry. $2006 a$. Climatology of winter cold spells in relation to mountain pine beetle mortality in British Columbia, Canada. Climate Res. 32:13-23.

Stahl, K., R.D. Moore, and I.G. McKendry. 2006b The role of synoptic-scale circulation in the linkage between large-scale ocean-atmosphere indices and winter surface climate in British Columbia, Canada. Int. J. Climatol. 26:541-560. DOI:10.1002/joc.1268.

Stathers, R.J., T.P. Rollerson, and S.J. Mitchell. 1994. Windthrow handbook for B.C. Forests. B.C. Min. For., Victoria, B.C. Work. Pap. No. 9401. www.for.gov.bc.ca/hfd/pubs/docs/wp/wpo1.pdf (Accessed March 2010).

Thompson, D.W.J. and J.M. Wallace. 1998. The Arctic oscillation signature in the wintertime geopotential height and temperature fields. Geophys. Res. Lett. 25:1297-1300.

Thornthwaite, C.W. 1948. Towards a rational approach to classification of climate. Geogr. Rev. 38:55-94.

Toews, D.A.A. 1991. Climatic and hydrologic circumstances antecedent to mass wasting events in southeastern British Columbia. In: Proc. 59th Annu. West. Snow Conf., April 12-15, 1991, Juneau, Alaska, pp. 91-102.

Trenberth, K.E. 1997. The definition of El Niño. Bull. Am. Meterol. Soc. 78:2771-2777.

Valentine, K.W.G., P.N. Sprout, T.E. Baker, and L.M. Lavkulich. 1978. The soil landscapes of British Columbia. B.C. Min. Environ., Resour. Anal. Br., Victoria, B.C.

Vincent, L.A. and E. Mekis. 2006. Changes in daily and extreme temperature and precipitation indices for Canada over the twentieth century. Atmos. Ocean 44:177-193.

Wang, T., A. Hamann, D.L. Spittlehouse, and S.N. Aitken. 2006. Development of scalefree climate data for western Canada for use in resource management. Int. J. Climatol. 26:383-397. www.for.gov.bc.ca/hre/pubs/docs/ Wang\%2oet\%20al2006.pdf (Accessed March 2010).

Whitfield, P.H. 2001. Linked hydrologic and climate variations in British Columbia and Yukon. Environ. Monit. Assess. 67:217-238.

Whitfield, P.H., K. Bodtker, and A.J. Cannon. 20o2a. Recent variations in seasonality of temperature and precipitation in Canada, 1976-1995. Int. J. Climatol. 22:1617-1644.

Whitfield, P.H. and A. Cannon. 20ooa. Recent variations in climate and hydrology of British Columbia and Yukon. Int. Hydrol. Programme. Contrib. IHP-v by Can. Experts. Unesco, Paris. Tech. Doc. Hydrol. No. 33, pp. 1-21. . 20oob. Recent variations in climate and hydrology in Canada. Can. Water Resour. J. 25:19-65.

Whitfield, P.H., C.J. Reynolds, and A.J. Cannon. 2002b. Modelling streamflows in present and future climates: examples from Georgia Basin, British Columbia. Can. Water Resour. J. $27(4): 427-456$.

Winkler, R., D. Spittlehouse, T. Giles, B. Heise, G. Hope, and M. Schnorbus. 2004. Upper Penticton Creek: how forest harvesting affects water quantity and quality. Streamline Watershed Manag. Bull. 8(1):18-20. www.forrex.org/ publications/streamline/ISS28/streamline vol8_no1_art6.pdf (Accessed March 2010).

Zhang, X., L.A. Vincent, W.D. Hogg, and A. Niitsoo. 2000. Temperature and precipitation trends in Canada during the 2oth century. Atmos. Ocean 38(3):395-429.

Zwiers, F.W. and X. Zhang. 2003. Toward regionalscale climate change detection. J. Climate 16:793-797. 